\title{
BLEND DOWN MONITORING SYSTEM FISSILE MASS FLOW MONITOR AND ITS IMPLEMENTATION AT THE SIBERIAN CHEMICAL ENTERPRISE, SEVERSK, RUSSIA
}

July 2005

Taner Uckan, José March-Leuba, Ray Carlton Brittain, and Danny Powell (ORNL)

Joseph Glaser (DOE) 


\title{
DOCUMENT AVAILABILITY
}

Reports produced after January 1, 1996, are generally available free via the U.S. Department of Energy (DOE) Information Bridge:

Web site: http://www.osti.gov/bridge

Reports produced before January 1, 1996, may be purchased by members of the public from the following source:

\author{
National Technical Information Service \\ 5285 Port Royal Road \\ Springfield, VA 22161 \\ Telephone: 703-605-6000 (1-800-553-6847) \\ TDD: 703-487-4639 \\ Fax: 703-605-6900 \\ E-mail: info@ntis.fedworld.gov \\ Web site: http://www.ntis.gov/support/ordernowabout.htm
}

Reports are available to DOE employees, DOE contractors, Energy Technology Data Exchange (ETDE) representatives, and International Nuclear Information System (INIS) representatives from the following source:

Office of Scientific and Technical Information

P.O. Box 62

Oak Ridge, TN 37831

Telephone: 865-576-8401

Fax: 865-576-5728

E-mail: reports@adonis.osti.gov

Web site: http://www.osti.gov/contact.html

This report was prepared as an account of work sponsored by an agency of the United States government. Neither the United States government nor any agency thereof, nor any of their employees, makes any warranty, express or implied, or assumes any legal liability or responsibility for the accuracy, completeness, or usefulness of any information, apparatus, product, or process disclosed, or represents that its use would not infringe privately owned rights. Reference herein to any specific commercial product, process, or service by trade name, trademark, manufacturer, or otherwise, does not necessarily constitute or imply its endorsement, recommendation, or favoring by the United States government or any agency thereof. The views and opinions of authors expressed herein do not necessarily state or reflect those of the United States government or any agency thereof. 
Nuclear Science and Technology Division

\title{
BLEND DOWN MONITORING SYSTEM FISSILE MASS FLOW MONITOR AND ITS IMPLEMENTATION AT THE SIBERIAN CHEMICAL ENTERPRISE, SEVERSK, RUSSIA
}

\author{
Taner Uckan, José March-Leuba, Ray Carlton Brittain, and \\ Danny Powell (ORNL) \\ Joseph Glaser (DOE)
}

Date Published: July 2005

Prepared by the OAK RIDGE NATIONAL LABORATORY

Oak Ridge, Tennessee 37831-6283 managed by

UT-BATTELLE, LLC

for the

U.S. DEPARTMENT OF ENERGY

under contract DE-AC05-00OR22725 



\section{CONTENTS}

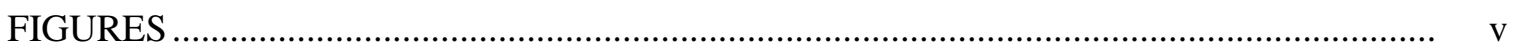

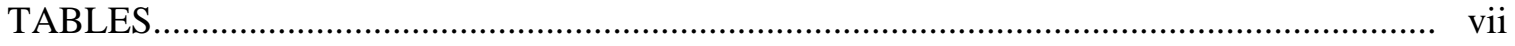

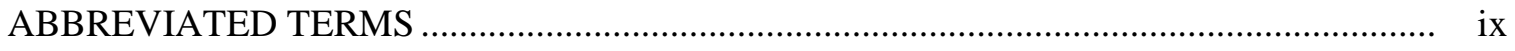

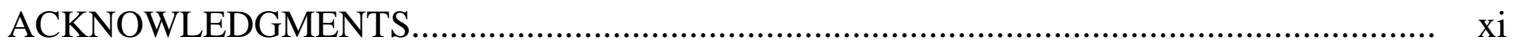

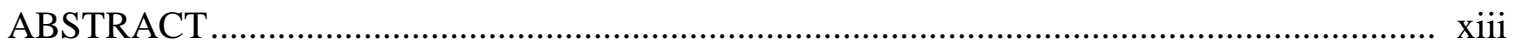

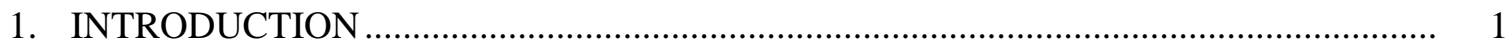

1.1 BLEND DOWN MONITORING SYSTEM BACKGROUND ….............................. 1

1.2 FMFM OPERATIONAL DESCRIPTION …...................................................... 2

2. SChE BDMS FMFM DESIGN STRATEGY …....................................................... 5

2.1 FMFM SM ASSEMBLY AND SUPPLEMENTAL SHIELDING …....................... 5

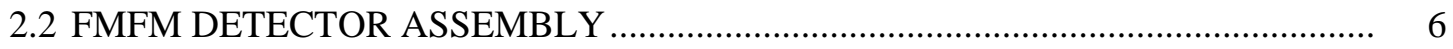

3. FMFM IMPLEMENTATION SPECIFICATIONS ....................................................... 7

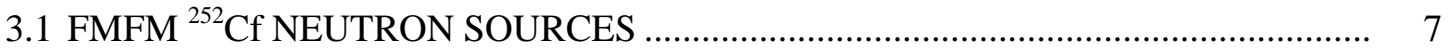

3.2 $\mathrm{UF}_{6}$ GAS PRESSURE AND FMFM FLOW REGIME OPERATIONS ..................... 7

3.3 FMFM MEASUREMENT PERFORMANCE PARAMETERS …................................. 8

3.4 RECOMMENDED FMFM EQUIPMENT INSTALLATION

CONFIGURATION FOR SChE ................................................................................ 8

4. BDMS IMPLEMENTATION STATUS AT SChE AND MEASUREMENT

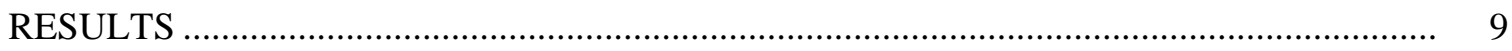

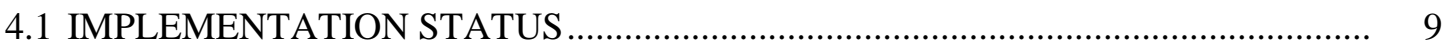

4.2 FMFM MEASUREMENT RESULTS _........................................................... 9

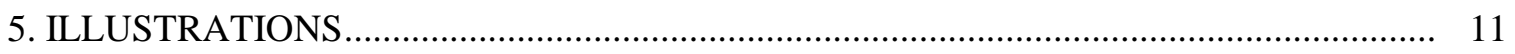

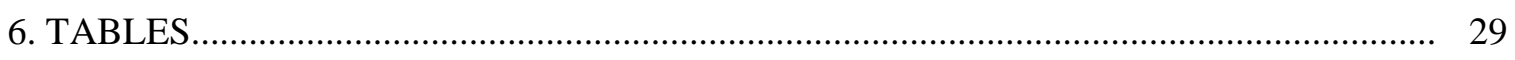

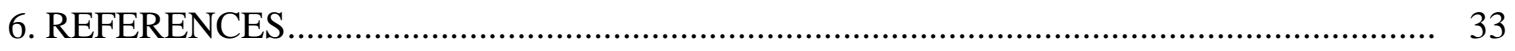





\section{FIGURES}

1. BDMS installed on an HEU blending tee......

2. The FMFM system operational principle is based on fission activation of $\mathrm{UF}_{6}$ gas in the flow stream

3. Measured FMFM detector signal waveform and the detector counts are collected every $100 \mathrm{~ms}$ as the shutter cycles

4. FMFM operational principle and the major assemblies and components.

5. Illustration of the FMFM HEU leg shutter motion pattern that generates the low-frequency modulation required for tracing the HEU flow to the P-LEU leg 15

6. Details of the FMFM source modulator and components 16

7. Details of the FMFM SM assembly and components.

8. FMFM source modulator shutter and source moderator subassembly

9. Photograph of the FMFM SM showing the lead shielding around the SM and the shutter positioner together with its motor and the controller.

10. Photograph of the FMFM source modulator showing the lithiated (5 wt \%) polyethylene shielding placed around the lead-covered source moderator and the additional high-density polyethylene biological neutron shielding panels placed on the sides

11. The FMFM gamma ray detector is a commercially available BGO scintillation detector (on the left) with a preamplifier, as shown from the top on the right

12. FMFM detector housing for the dual BGO detectors, including the detector electronics cards, DIEC, and SNC.

13. FMFM detector assembly designed for 8 -in.-diam $\mathrm{UF}_{6}$ process pipes.

14. Detailed engineering design drawing of the FMFM detector assembly, showing a cross sectional view around the process pipe.

15. Detailed view of the FMFM detector housing together with the DIEC and SNC

16. Photographs of (left) the FMFM detector assembly showing the additional lead gamma shield located toward the FMFM sources to reduce the detector background signal and (right) the DSPD box.

17. Block diagram of the BDMS installation on the HEU blending system at SChE. 23

18. Typical SChE FMFM equipment 23 
19. BDMS main cabinet, which houses the EM and FMFM cabinet sections ........................ 24

20. Recommended FMFM installation configuration for HEU leg....................................... 24

21. Recommended FMFM installation configuration for the LEU and P-LEU legs................. 25

22. The recommended FMFM installation configurations for all three legs are designed to reduce the crosstalk among the sources in the source modulators and the detectors ....... 25

23. SChE BDMS training for the Russian delegation at ORNL, May 17-21, 2004 ................ 26

24. The Russian delegation practicing on the source modulator installation ............................ 26

25. The Russian delegation in a classroom discussion of the BDMS installation..................... 27

26. BDMS equipment in the SChE Enrichment Plant BDMS room

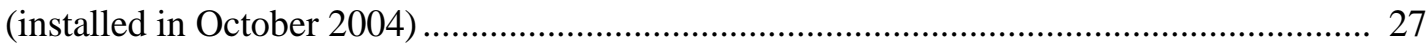




\section{TABLES}

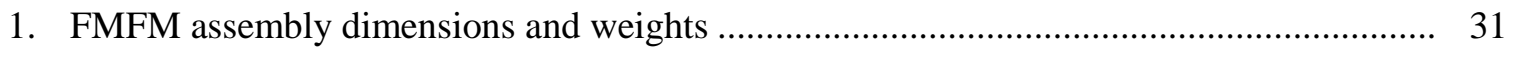

2. FMFM $\mathrm{UF}_{6}$ gas velocity ranges during operation .................................................... 31

3. FMFM flow measurement range and associated uncertainty ....................................... 31

4. BDMS operating pressures and the FMFM measurement results .................................. 31 



\section{ABBREVIATED TERMS}

BDMS Blend Down Monitoring System

BGO bismuth germanium oxide

DIEC detector interface electronics card

DOE U.S. Department of Energy

DSPD detector signal power distribution

ECP Electro Chemical Plant (Zelenogorsk)

EM Enrichment Monitor

FMFM Fissile Mass Flow Monitor

HEU highly enriched uranium

LEU low enriched uranium

ORNL Oak Ridge National Laboratory

P-LEU product low enriched uranium

RosAtom Russian Federal Atomic Energy Agency

SA summing amplifier

SChE Siberian Chemical Enterprise (Seversk)

SM source modulator

SNC sensor network card

TIP Transparency Implementation Program

UEIP Ural Electrochemical Integrated Plant (Novouralsk)

VGA variable-gain shaping amplifier 



\section{ACKNOWLEDGMENTS}

The authors wish to thank Kim N. Castleberry, Richard W. Jones, Carl W. Martin, Ken S.

Weaver, and Wes R. Wysor (Engineering Science and Technology Division) for their relentless

help in making the BDMS FMFM a reality in a short time period without any compromises. 



\begin{abstract}
In this paper the implementation plans and preparations for installation of the Fissile Mass Flow Monitor (FMFM) equipment at the Siberian Chemical Enterprise (SChE), Seversk, Russia, are presented. The FMFM, developed by Oak Ridge National Laboratory, is part of the Blend Down Monitoring System (BDMS) for the U.S. Department of Energy Highly Enriched Uranium (HEU) Transparency Implementation Program. The BDMS provides confidence to the United States that the Russian nuclear facilities supplying the lower assay ( 4\%) product low enriched uranium (PLEU) to the United States from down-blended weapon-grade HEU are meeting the nonproliferation goals of the government-to-government HEU purchase agreement signed between the Russian Federation and the United States in 1993.
\end{abstract}

The first BDMS has been operational at Ural Electrochemical Integrated Plant, Novouralsk, since February 1999. The second BDMS has been operational at Electro Chemical Plant, Zelenogorsk, since March 2003. These systems are successfully providing HEU transparency data to the United States. The third BDMS was successfully installed on the HEU down-blending tee in the SChE Enrichment Plant in October 2004.

The FMFM makes use of a set of thermalized ${ }^{252} \mathrm{Cf}$ spontaneous neutron sources for modulated fission activation of the $\mathrm{UF}_{6}$ gas stream for measuring the ${ }^{235} \mathrm{U}$ fissile mass flow rate. To do this, the FMFM measures the transport time of the fission fragments created from the fission activation process under the modulated source to the downstream detectors by detecting the delayed gamma rays from the fission fragments retained in the flow. The FMFM provides unattended nonintrusive measurements of the ${ }^{235} \mathrm{U}$ mass flow of the $\mathrm{UF}_{6}$ gas in the blending tee legs of HEU, the LEU blend stock, and the resulting P-LEU. The FMFM also confirms that highly enriched $\mathrm{UF}_{6}$ gas identified in the HEU leg flows through the blending tee into the P-LEU leg. This report contains details of the SChE FMFM equipment characteristics as well as the technical installation requirements and the latest measurement results. 



\section{INTRODUCTION}

\subsection{BLEND DOWN MONITORING SYSTEM BACKGROUND}

The Blend Down Monitoring System (BDMS) is a system for monitoring the down-blending of highly enriched uranium (HEU) to low enriched uranium (LEU). The BDMS measures the enrichment and flow rate of ${ }^{235} \mathrm{U}$ in the gaseous $\mathrm{UF}_{6}$ flowing in the three lines (legs) of the blending facility (Fig. 1). The HEU Transparency Agreement between the United States and the Russian Federation requires implementation of transparency measures in the Russian facilities that are supplying the lower assay product LEU (P-LEU) to the United States from down-blended weapon-grade HEU material. Moreover, this agreement provides for the monitoring of the downblending of HEU at an assay of $\sim 90 \%$ with blend stock LEU at an assay of $\sim 1.5 \%$ to produce reactor-grade P-LEU at an assay of $\sim 4 \%$ to be used in U.S. nuclear power plants.

The BDMS has been developed to provide unattended and continuous monitoring of the HEU blending operations at the Russian facilities as part of the U.S. Department of Energy (DOE) HEU Transparency Implementation Program (TIP). The BDMS consists of the Enrichment Monitor (EM), developed by the Los Alamos National Laboratory [1], and the Fissile Mass Flow Monitor (FMFM), developed at Oak Ridge National Laboratory (ORNL) [2]. The FMFM provides measurements of ${ }^{235} \mathrm{U}$ mass flow in the process legs of HEU, the LEU blend stock, and the resulting lower-assay P-LEU. The FMFM also traces fission products generated in the HEU flow through the blending tee into the resulting down-blended P-LEU flow, thus confirming down-blending of the HEU. The HEU material traceability gives the United States significant confidence that the HEU is indeed being blended into a lower-assay material, meeting the nonproliferation goal of the purchase agreement.

The first BDMS has been operational at the Ural Electrochemical Integrated Plant (UEIP), Novouralsk, since February 1999. The second BDMS has been operational at the Electro Chemical Plant (ECP), Zelenogorsk, since March 2003. These systems are successfully providing HEU transparency data to the United States. The third BDMS was successfully installed on the HEU down-blending tee in the Siberian Chemical Enterprise (SChE) Enrichment Plant in October 2004. In this report, details of the FMFM implementation in the SChE Enrichment Plant are discussed. 


\subsection{FMFM OPERATIONAL DESCRIPTION}

The principle behind the FMFM operation is that the fissile mass flow rate can be determined from measurements of delayed gamma rays emitted by induced fission fragments (Fig. 2). The source neutrons modulated by a neutron-absorbent shutter induce fissions in $\mathrm{UF}_{6}$, and the fission fragments carried in the flowing $\mathrm{UF}_{6}$ emit delayed gamma rays. The induced fissions are timemodulated by the neutron-absorbing shutter to create a time signature in the $\mathrm{UF}_{6}$ gas flow. Gamma-ray detectors located downstream of the source measure the delayed gamma rays $(>0.3$ $\mathrm{MeV}$ ) emitted by the fission fragments. Then, the FMFM determines the fissile mass flow rate from two independent measurements from the detector signal waveform (Fig. 3): (1) the observed time delay, $\tau$, in the time-correlated measurement between the source and the detector signal provides the velocity, $\sim 1 / \tau$, of the $\mathrm{UF}_{6}$, and (2) the signal's amplitude is related to the ${ }^{235} \mathrm{U}$ concentration in the $\mathrm{UF}_{6}$. The details of the FMFM models employed to predict the FMFM detector response are discussed in earlier publications [3, 4].

The major FMFM assemblies and components are shown in Fig. 4. The FMFM source modulator (SM) assembly is an annular sleeve that surrounds the pipe in which $\mathrm{UF}_{6}$ flows. It contains thermalized ${ }^{252} \mathrm{Cf}$ neutron sources in a moderator material (high-density polyethylene).

The principle of the FMFM HEU traceability measurement is that the highly enriched $\mathrm{UF}_{6}$ flowing through the blending tee can be traced by detecting in the P-LEU leg the delayed gamma rays emitted by fission products generated by the SM in the HEU leg (Fig. 1). The fission fragments that are created from the ${ }^{252} \mathrm{Cf}$-induced fissions are relatively long-lived [4]. Thus their delayed gamma rays can be detected at long distances from the source. This technique is used to monitor flow continuity from the FMFM SM on the HEU leg to the FMFM detector on the PLEU leg.

The FMFM tracing calculation is based on the difference in total count rate at the P-LEU detector with and without the HEU leg shutter in operation. The FMFM reports the HEU tracing results in terms of confidence level, which is a measure of the probability that the HEU flowed through the blending tee. The time constant for the low-frequency "tagging signal" must be optimized based on the source-detector time delay and the number of mixing volumes. For the SChE system the FMFM cycles the HEU leg shutter open and closed every $10 \mathrm{~s}$ for a 10-min period and then is closed for the next 10-min period (Fig. 5). The 20-min cycle results in a buildup and decay of 
fission products that allow for continuity monitoring by comparing the difference in the P-LEU leg detector counts with and without induced fissions. Disabling the HEU-leg shutter periodically (every other $10 \mathrm{~min}$ ) affects the shutter-correlated background level at the P-LEU leg detector. Therefore, for traceability, the FMFM only uses the data when all shutters are closed. An on-line FMFM computer, located in the cabinet assembly (see Fig. 4), controls all three leg SM shutters synchronously, processes acquired detector data, and reports results on the flow and trace measurements. 



\section{SChE BDMS FMFM DESIGN STRATEGY}

The FMFMs implemented at the UEIP and the ECP were designed for nominal 10-cm-diam UF $_{6}$ process pipes. In the case of low enriched $\mathrm{UF}_{6}$ flow measurements on the LEU leg $(\sim 1.5 \%$ enriched) and the P-LEU leg ( 4\% enriched), the detector signal, $N_{\mathrm{s}}$, from the delay gamma rays needs to be increased in order to achieve the measurements within a short period of time (less than the process duration) with statistically acceptable measurement results (measurement confidence level $>90 \%$ ) because the measurement convergence time $\tau_{\mathrm{c}} \sim N_{\mathrm{b}} / N_{\mathrm{s}}{ }^{2}$, where $N_{\mathrm{b}}$ is the room background. This is only possible by increasing the delay gamma ray source that results

from the fission activation of the $\mathrm{UF}_{6}$ flowing in the process pipe. Using more ${ }^{252} \mathrm{Cf}$ is not a viable option because the facility dose rate requirement must be maintained. Therefore, the desired higher detector signal is achieved by increasing the active volume of the fission process (i.e., by using a larger-diameter process pipe) and thus having a higher volume of fission fragments flowing in the $\mathrm{UF}_{6}$ gas stream. The FMFMs for the SChE LEU and P-LEU legs were designed for nominal 20-cm-diam process pipes, and the facility modified the enrichment plant process pipes, which are part of a dedicated BDMS room, to accommodate the equipment, as discussed in detail in Ref. [5].

\subsection{FMFM SM ASSEMBLY AND SUPPLEMENTAL SHIELDING}

The FMFM SM assembly (Figs. 6 and 7) is located upstream from the FMFM detector assembly. The purpose of the SM is to imprint a time-dependent signature on the fissile stream by modulating the ${ }^{252} \mathrm{Cf}$ source neutrons. The four ${ }^{252} \mathrm{Cf}$ sources that provide the neutrons required for activation of the $\mathrm{UF}_{6}$ process gas stream are mounted in source plugs that fit into the moderator subassemblies (Fig. 8). The sources are oriented perpendicularly to the process pipe and are spaced at 90-degree intervals. The subassemblies and plugs are made of high-density polyethylene, which moderates the fast neutrons emitted by the sources.

The modulation of the neutron flux intensity is accomplished by using a cylindrical aluminum shutter with a lithium-epoxy (neutron absorber) lining (Fig. 8). A voided section in the lithiumepoxy lining creates a window region. The shutter mounts to the linear positioner subassembly. The linear positioner subassembly moves the shutter to modulate the neutron flux intensity. The movement of the shutter assembly results in a modulation of the neutron flux intensity in the $\mathrm{UF}_{6}$ process gas stream. The positioner contains an integral stepping motor (Fig. 9) that is powered by 
the FMFM cabinet assembly and controlled by the FMFM software and by a controller mounted in the SM assembly.

The SM assembly is shielded to reduce the surface radiation levels, as shown in Figs. 6 and 7. A layer of lead shielding encloses the moderator (Fig. 9). A layer of lithium-impregnated (5 wt \%) polyethylene shielding surrounds the lead shielding (Fig. 10). The shielding was designed in segments so that the weight and size of shielding components are reduced for easier handling during installation and maintenance operations. Sheets of high-density polyethylene shielding are also installed at each end of the SM assembly frame (Fig. 10). Both high-density polyethylene and lead supplemental shielding components are provided for installation on the process pipe to augment SM assembly shielding as needed to meet facility radiation standards. In addition, the SM assembly is covered with about 7.5-cm thick polyethylene shielding panels on the front, the back, and the top.

\subsection{FMFM DETECTOR ASSEMBLY}

More detectors are needed for the large-diameter $(20-\mathrm{cm})$ process pipes than the number used in 10-cm-diam pipes (see Fig. 4). Increasing the number of detectors results in a higher detection efficiency, or higher detector solid angle, $\Omega_{\mathrm{d}}$, which results in a higher detection signal because the signal value, $N_{\mathrm{s}}$, is related to the $\Omega_{\mathrm{d}}$ of the detector as seen from the gamma ray source. (Here, $\Omega_{\mathrm{d}}$ is defined by an integral over the detector area that faces the gamma ray source.) In reference [6], a detailed design description and the performance characteristics are presented for the FMFM gamma ray detector system developed to be used on 20-cm-diam process pipes. Four pairs of bismuth germinate (BGO) scintillation detectors are placed around the process pipe, on the top, bottom, front, and back (see Figs. 4, 11, 12, and 13). The BGO is a novel scintillation material (a rugged, nonhygroscopic, neutron-insensitive, high-density and high- $Z$ material) with high absorption power. It has high photo peak efficiency for high-energy delay gammas (>0.3 MeV). Each 10-cm-diam, 5-cm-thick BGO scintillation crystal is coupled to an 8-cm-diam photomultiplier tube. Both are shielded with lead to reduce the background signal (Fig. 14). Each detector pair is housed in a metal enclosure that also contains an electronics board for signal shaping and counting (Figs. 15 and 16). 


\section{FMFM IMPLEMENTATION SPECIFICATIONS}

The block diagram of the BDMS equipment installation layout on the SChE HEU blending system is shown in Fig. 17. Typical examples of the FMFM equipment, the SM, and the detector assemblies installed on a test stand is shown in Fig. 18. The EM and FMFM cabinet sections are shown in the main cabinet housing in Fig. 19. The blending system process pipes that directly support the FMFM equipment where the BDMS is installed are about $1 \mathrm{~m}$ off the floor in order to have easy access to the equipment for maintenance. The major FMFM assembly dimensions and approximate weights are given in Table 1 . The facility radiation dose rate requirement, which is $2 \mathrm{mrem} / \mathrm{h}$ at $1 \mathrm{~m}$ from the surface of the equipment that houses the radioactive sources, is met by the design of the FMFM SM assemblies and has been verified with measurements for certification.

\subsection{FMFM ${ }^{252}$ Cf NEUTRON SOURCES}

The FMFM SM on the each leg of the blending system uses a total of four neutron sources. Each has $3 \mu \mathrm{g}$ of ${ }^{252} \mathrm{Cf}$ (half-life $\sim 2.65$ years), the equivalent of $1.65 \mathrm{mCi}$. These sources provide a total of about $2.6 \times 10^{7}$ neutrons per second for fission activation of the $\mathrm{UF}_{6}$ gas flow under the SM. As shown in Fig. 8, the four high-density polyethylene source plugs that hold the sources in the SM are evenly distributed around the SM. The radial location of the sources was determined from Monte Carlo modeling studies for maximizing the thermal neutron flux under the SM [2]. The sources need to be replaced about every two years to maintain FMFM performance.

\subsection{UF 6 GAS PRESSURE AND FMFM FLOW REGIME OPERATIONS}

The recommended $\mathrm{UF}_{6}$ gas pressure range for the FMFM equipment operation is between 50 and 60 Torr (regulated) at the locations of the FMFM equipment. The FMFM can operate with either laminar or turbulent $\mathrm{UF}_{6}$ gas flow. At $\mathrm{SChE}$, the FMFM is designed to measure the laminar flow of the HEU leg and the turbulent flow of the LEU and P-LEU legs. Table 2 specifies the range of gas velocities that the FMFM can measure. 


\subsection{FMFM MEASUREMENT PERFORMANCE PARAMETERS}

Table 3 shows the system performance specifications for the range of variables over which the FMFM is designed to operate, along with their measurement uncertainty.

\subsection{RECOMMENDED FMFM EQUIPMENT INSTALLATION CONFIGURATION FOR SChE}

Figures 20 and 21 show the recommended installation configuration for the FMFM assemblies for the HEU, LEU, and P-LEU legs at the SChE facility. The SM-to-detector separation distances, $L$, optimized for these process legs, are obtained from simulation modeling studies [3] to achieve the design performance (i.e., given the shutter period and detector background, the time delay, $\tau$, was optimized for the expected velocity, $L / \tau$, range of measurements). The FMFM assemblies include supplemental polyethylene neutron shielding (Figs. 20 and 21). Figure 22 shows the recommended schematic of the complete FMFM system equipment installation configuration for the blending system. In order to improve the measurement convergence time, $\tau_{c}$, the proposed configuration lowers the crosstalk (background signal, $N_{\mathrm{b}}$ ) from sources such as minimum back shine from the SM to detectors between the HEU, P-LEU, and LEU process legs. In addition, as shown in Fig. 21, supplemental gamma shielding may be installed to further lower the FMFM detector background signal from the sources in the SM on the HEU, LEU, and P-LEU legs. 


\section{BDMS IMPLEMENTATION STATUS AT SChE AND MEASUREMENT RESULTS}

\subsection{IMPLEMENTATION STATUS}

In May 2004, a Russian delegation participated in a week of training at ORNL on the operation and installation of the BDMS equipment (see Figs. 23 through 25). In June 2004, after more than a month of complete system operational testing at ORNL, the BDMS equipment was packed in 37 crates and was shipped to SChE. The joint U.S. and SChE inventory of the crates was performed in September 2004, and the required 30-day security inspection by the Russian Federal Atomic Energy Agency (RosAtom) was also completed. DOE prepared the recommended installation schedule and provided it to RosAtom.

BDMS implementation was accomplished at SChE in two steps. In October 2004, the BDMS hardware was successfully installed to the SChE Enrichment Plant (Fig. 26) [5]. In February 2005, the system was calibrated and was accepted for operation by RosAtom to be used for the DOE HEU TIP. The main BDMS implementation activities during February 2005 were to (1) perform background measurements on the evacuated piping, (2) complete calibration of the system, (3) work with the Russian Certification Commission selected by RosAtom to verify that the system met its criteria and that the system was placed into transparency operation, and (4) confirm operation of the installed system. All four objectives were successfully accomplished, and the Russian Commission approved the SChE BDMS for transparency operation. The following details of the SChE implementation and results are discussed in Ref. [5]: (1) the characteristic features of the BDMS configuration at the SChE Enrichment Plant blending facility; (2) the process technology of the pipelines preparation for the BDMS installation; (3) personnel training; (4) installation of the system together with the sources of ionizing radiation; and (5) the BDMS setup, testing, and certification process.

\subsection{FMFM MEASUREMENT RESULTS}

The FMFM has been operational without any hardware failure since its installation and has not required any maintenance activity. The FMFM measurement results are summarized in Table 4, where the ranges of $\mathrm{UF}_{6}$ gas pressure and the flow values relative to the SChE plant measurements are given for each flow monitor location [5]. The flow measurement results from the FMFM are in good agreement with the plant data, and the measurement uncertainties are well 
below the FMFM design specifications (as indicated in Table 3). The measurements of the traceability of highly enriched $\mathrm{UF}_{6}$ to the P-LEU leg were also very good; the measured FMFM values were in the range of 65 to $99 \%$, confirming the HEU down blending [5]. 


\section{ILLUSTRATIONS}





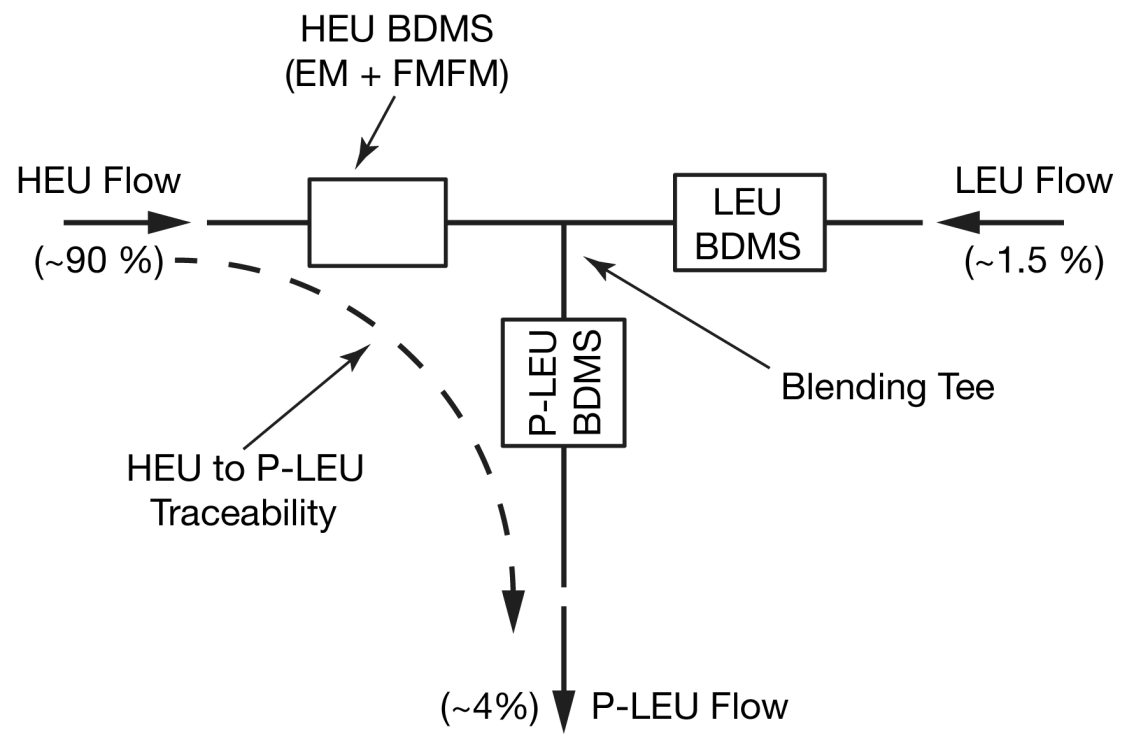

Fig. 1. BDMS installed on an HEU blending tee.

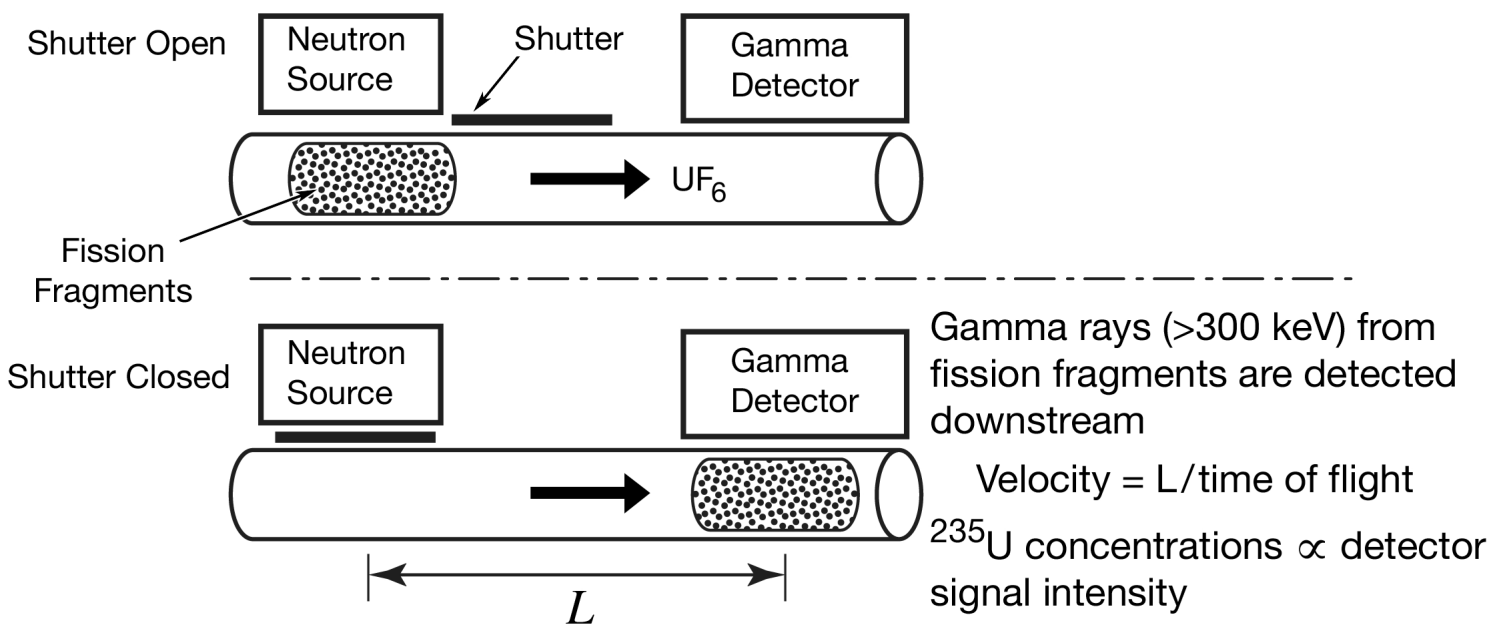

Fig. 2. The FMFM system operational principle is based on fission activation of $\mathrm{UF}_{6}$ gas in the flow stream. When the shutter opens, fissions are induced and the $\mathrm{UF}_{6}$ stream carries the fragments downstream. Fissile Mass Flow Rate $(\mathrm{g} / \mathrm{s})=$ Velocity $(\mathrm{m} / \mathrm{s}) \times{ }^{235} \mathrm{U}$ Concentration $(\mathrm{g} / \mathrm{m})$. 


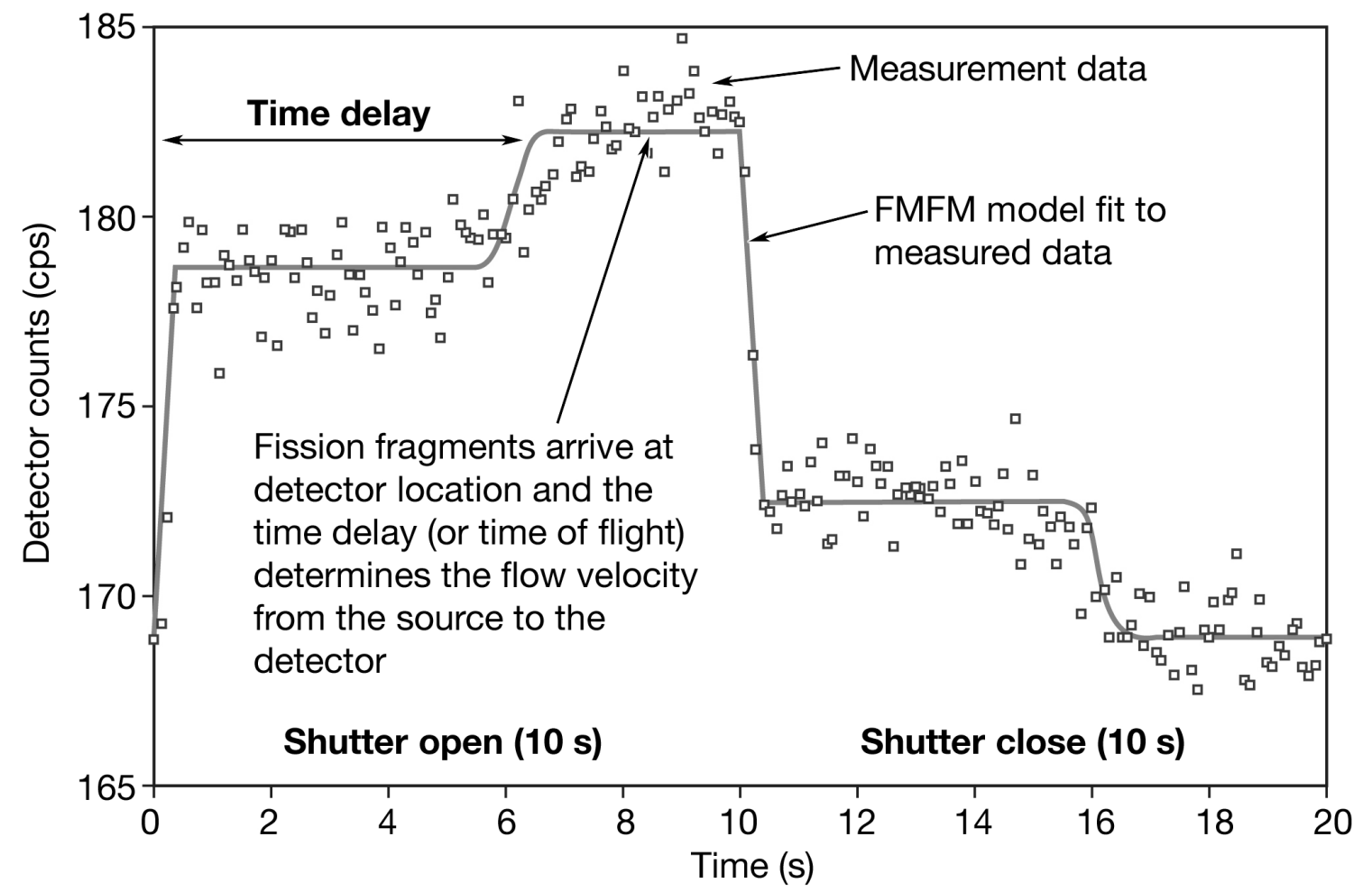

Fig. 3. Measured FMFM detector signal waveform and the detector counts are collected every 100 ms as the shutter cycles. 


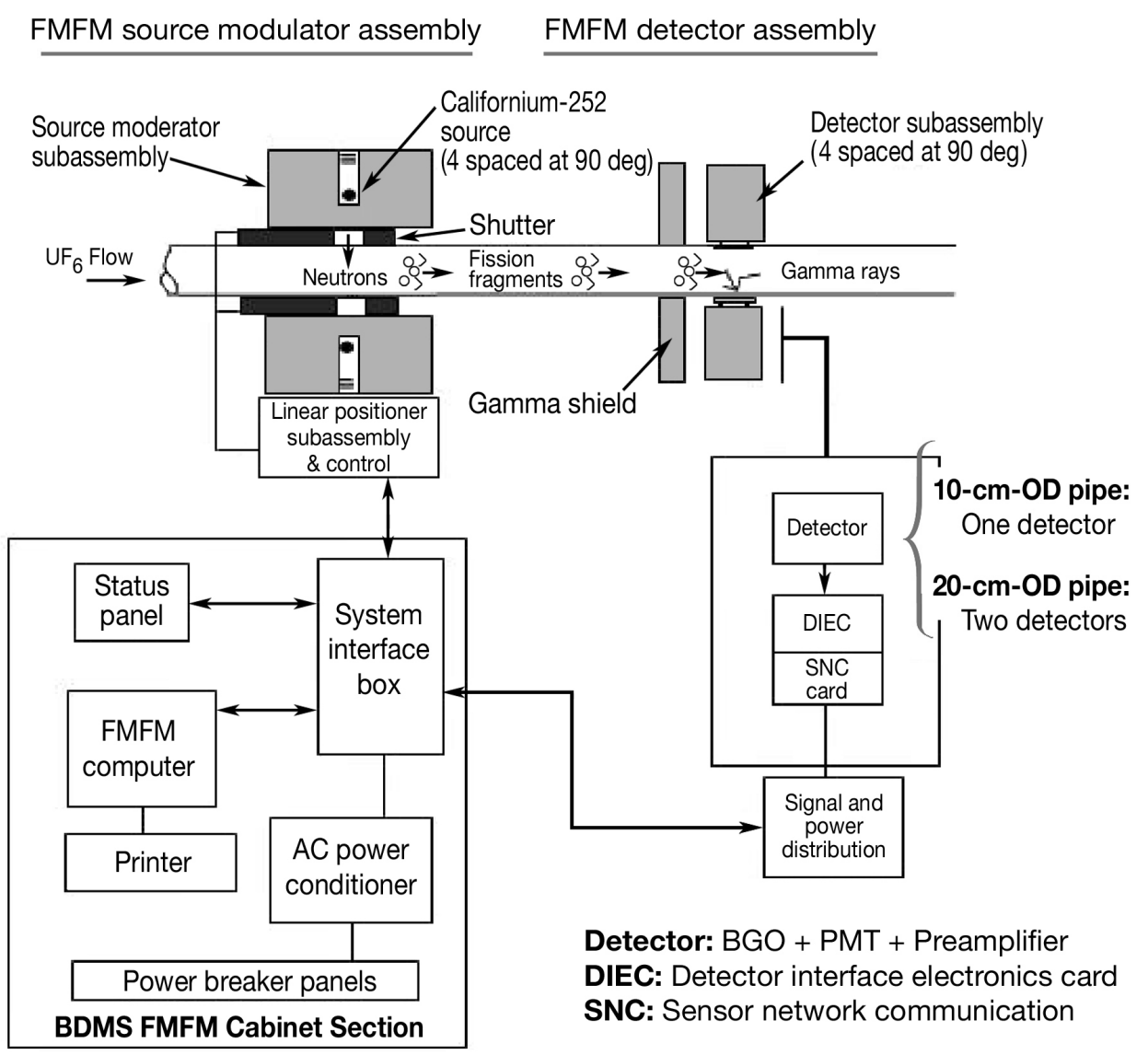

Fig. 4. FMFM operational principle and the major assemblies and components.

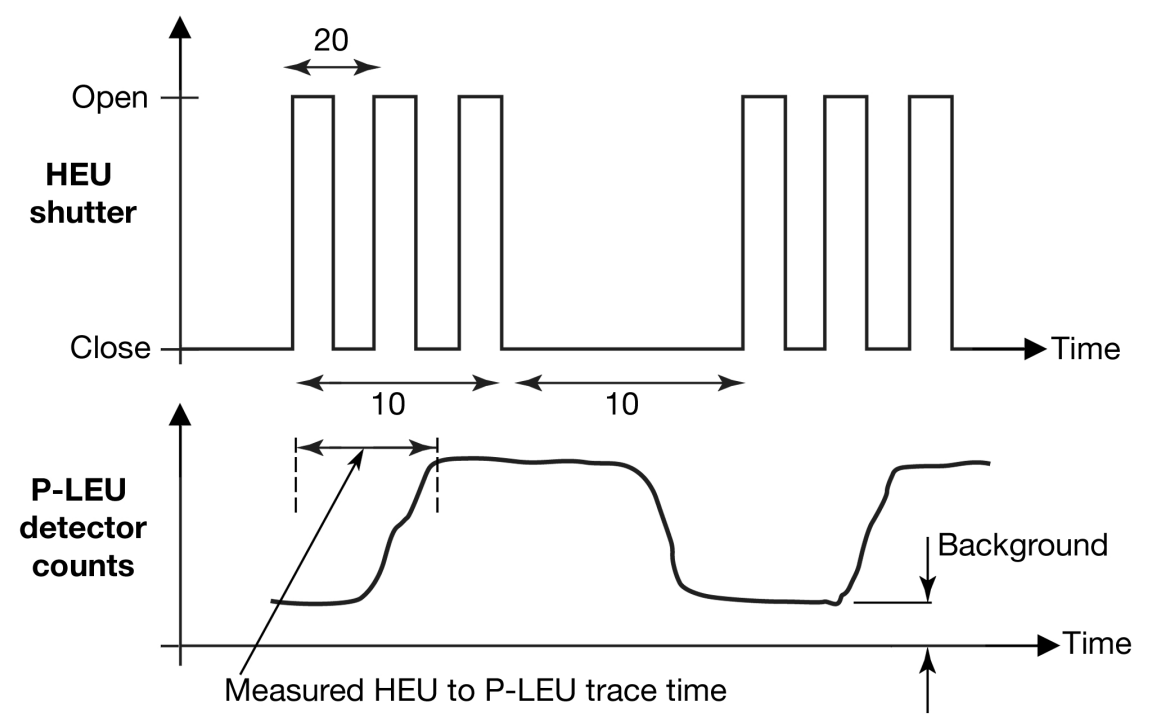

Fig. 5. Illustration of the FMFM HEU leg shutter motion pattern that generates the low-frequency modulation required for tracing the HEU flow to the P-LEU leg. 


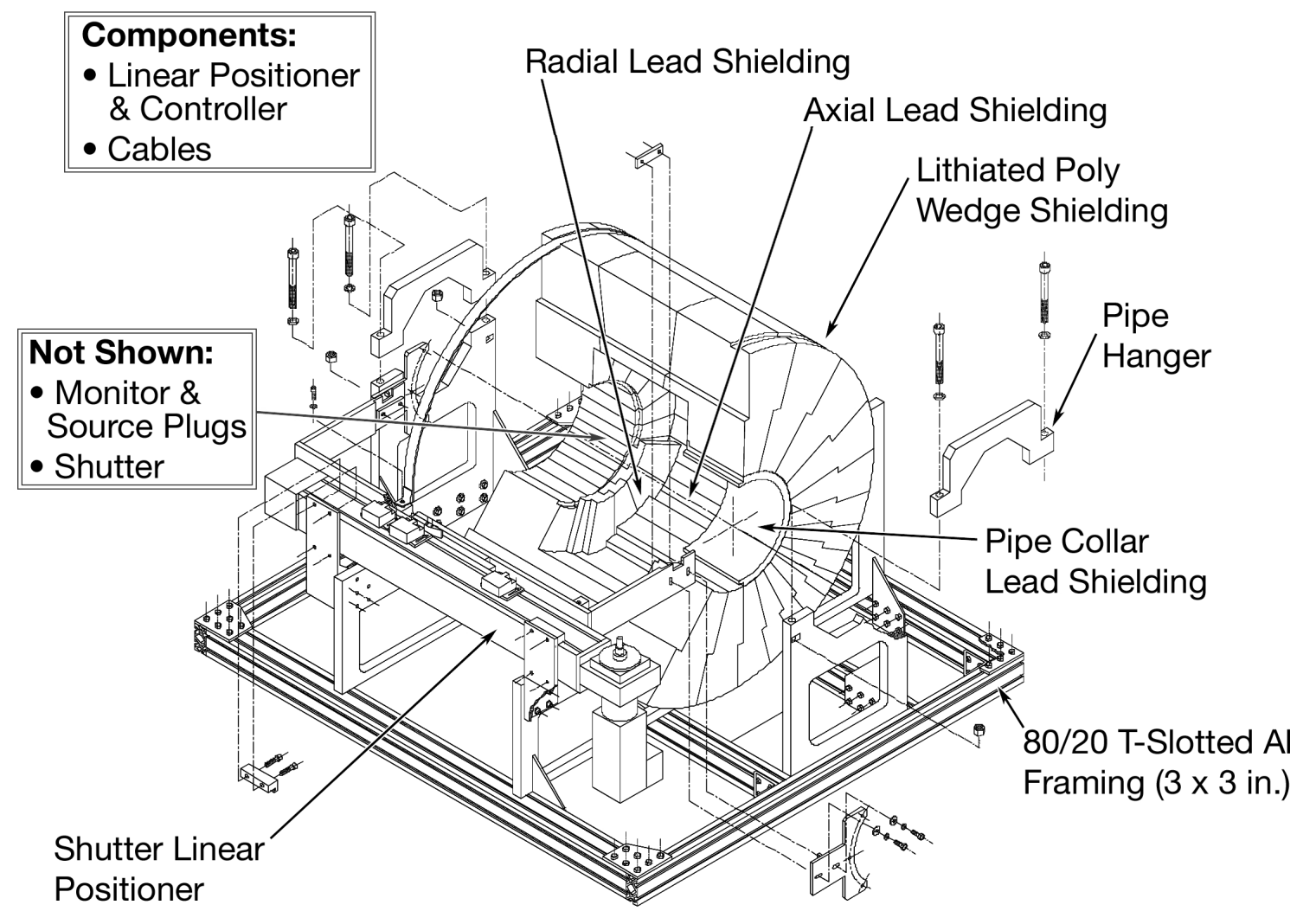

Fig. 6. Details of the FMFM source modulator and components. 


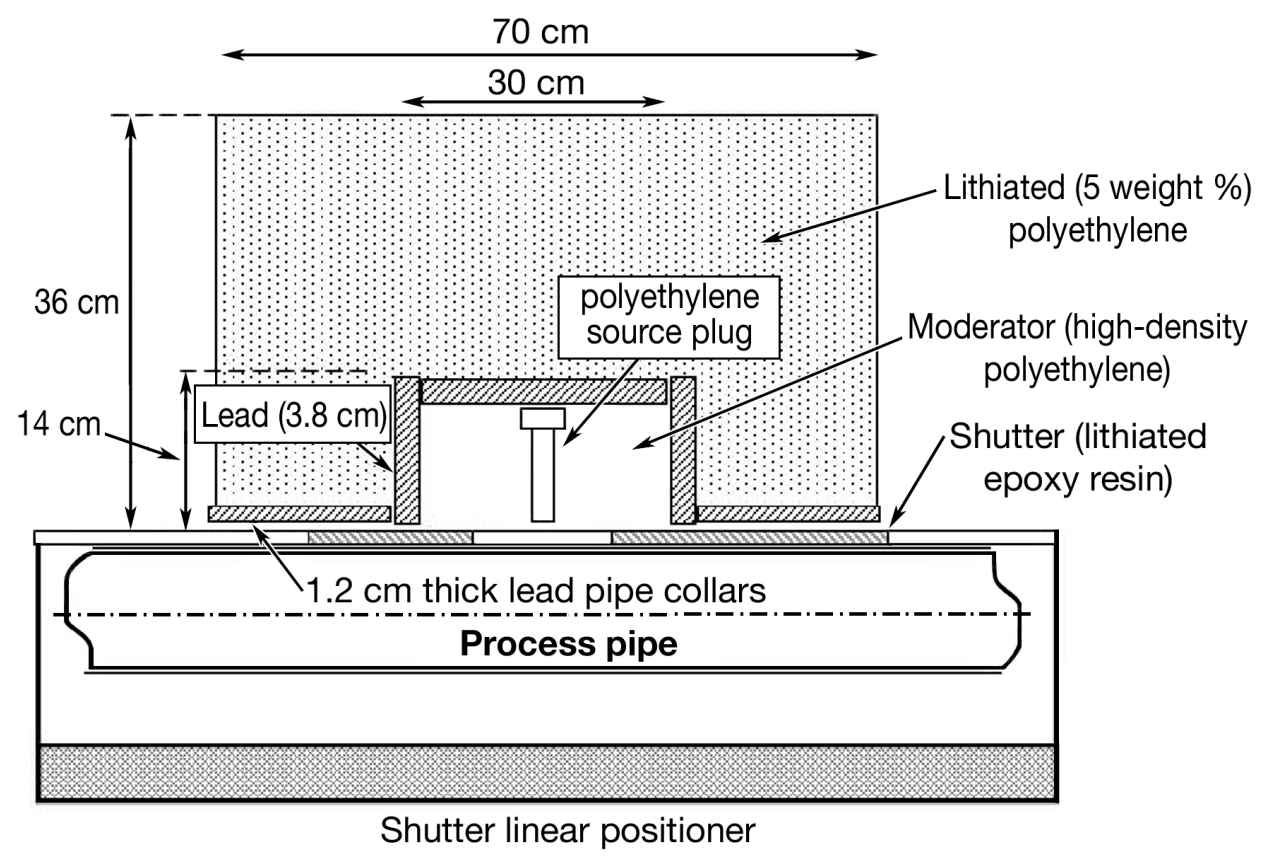

Fig. 7. Details of the FMFM SM assembly and components.

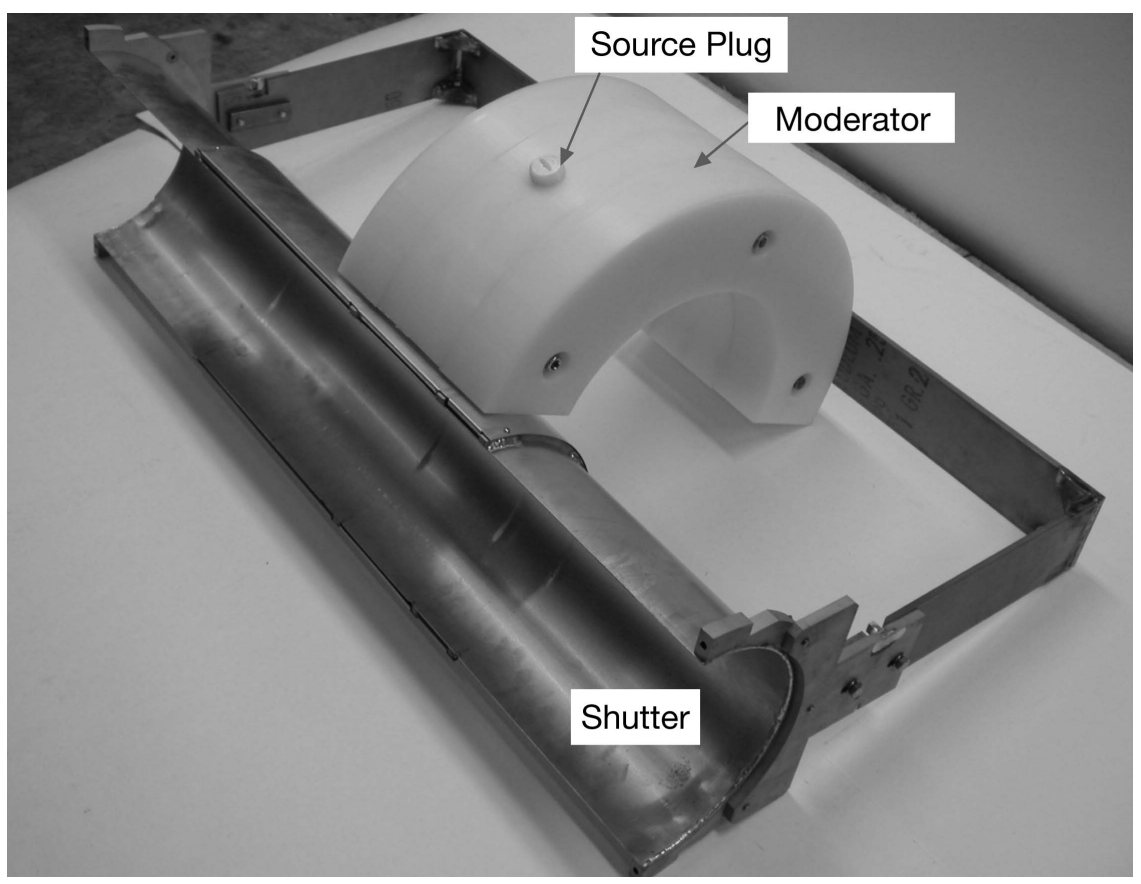

Fig. 8. FMFM source modulator shutter and source moderator subassembly. 


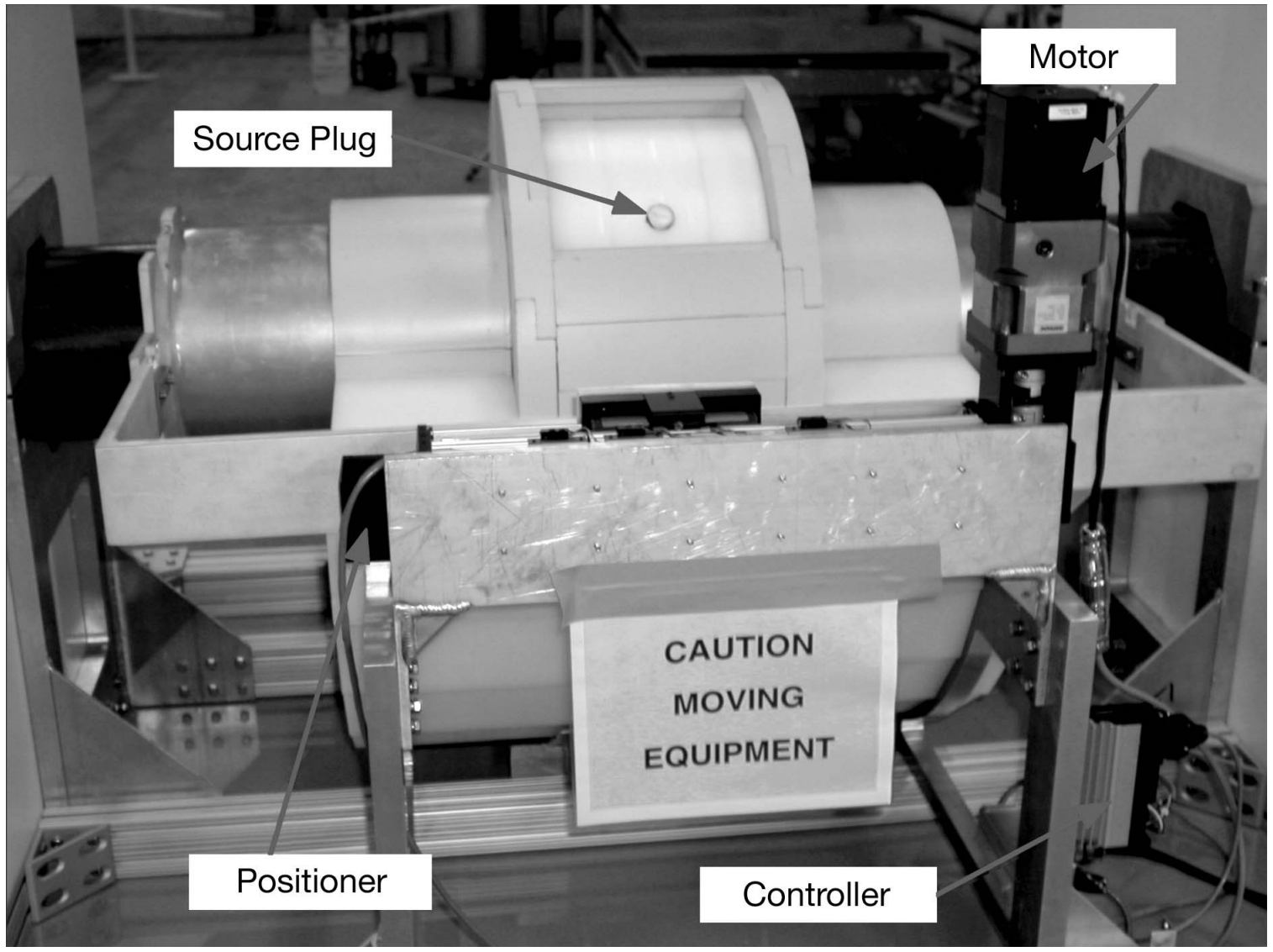

Fig. 9. Photograph of the FMFM SM showing the lead shielding around the SM and the shutter positioner together with its motor and the controller. 


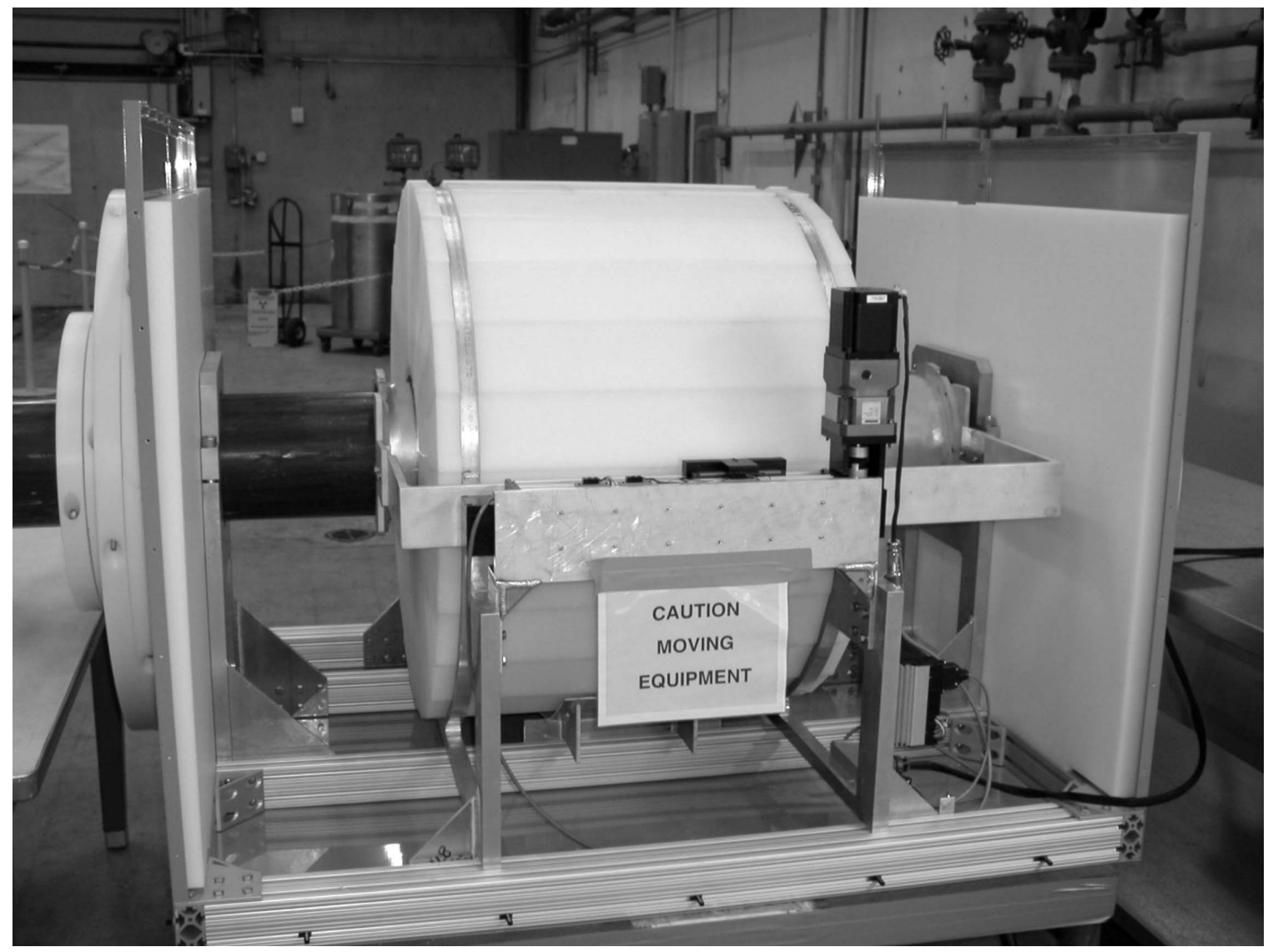

Fig. 10. Photograph of the FMFM source modulator showing the lithiated (5 wt \%) polyethylene shielding placed around the lead-covered source moderator and the additional high-density polyethylene biological neutron shielding panels placed on the sides. 

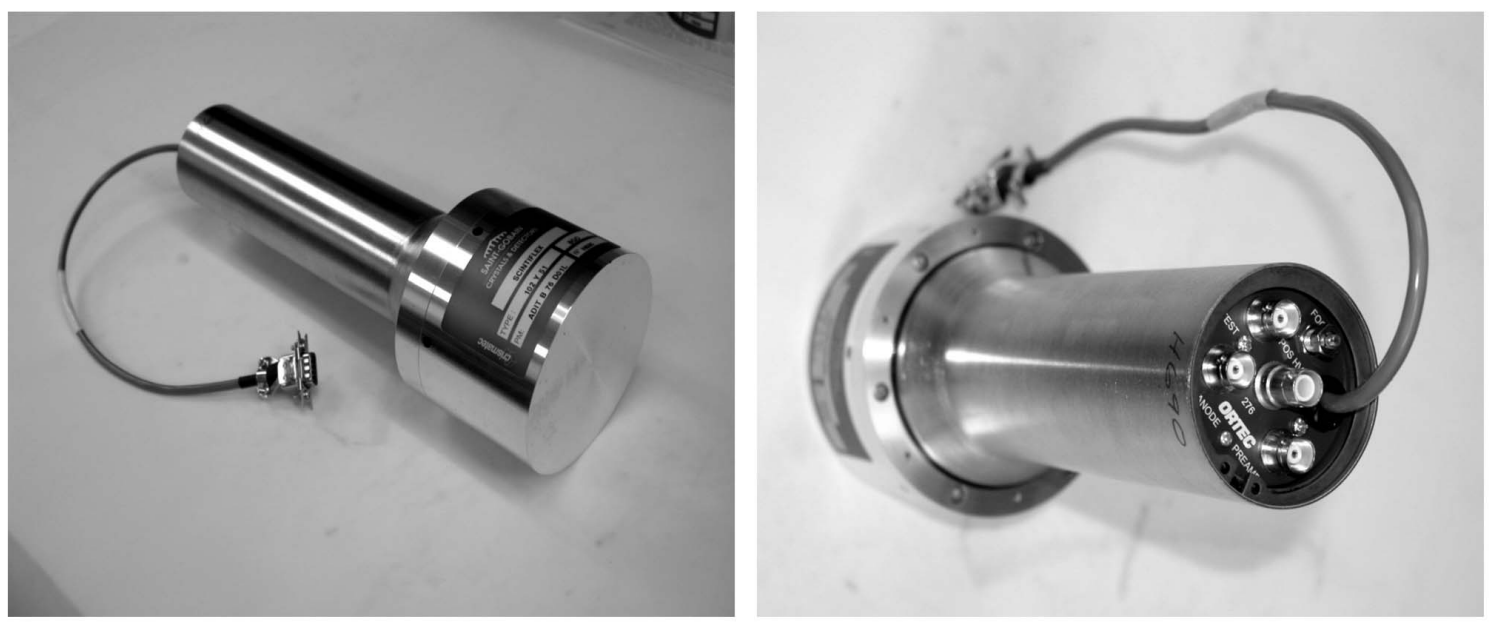

Fig. 11. The FMFM gamma ray detector is a commercially available BGO scintillation detector (on the left) with a preamplifier, as shown from the top on the right.

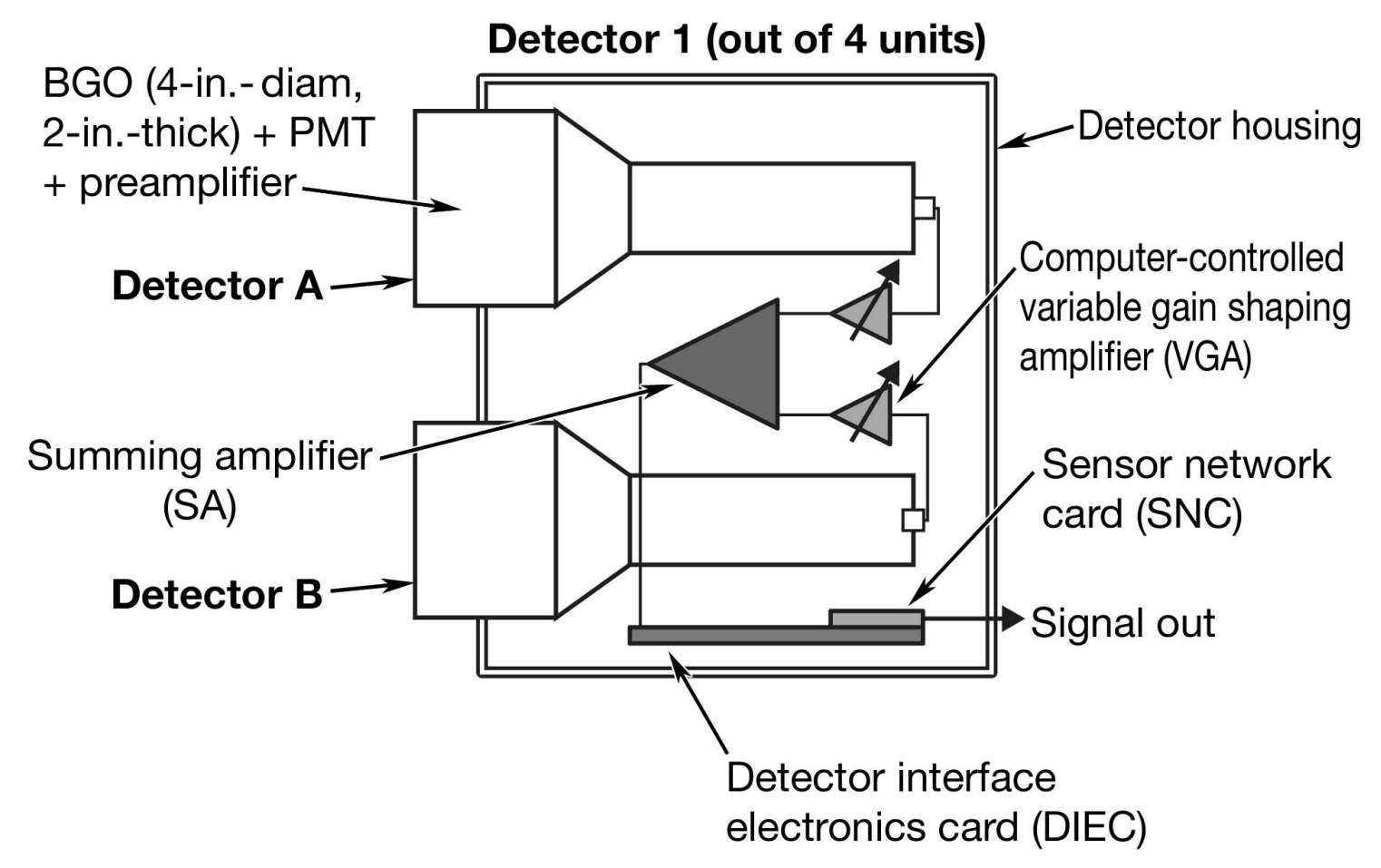

Fig. 12. FMFM detector housing for the dual BGO detectors, including the detector electronics cards, DIEC, and SNC. The VGA and SA, shown separately for illustration, are part of the DIEC. 


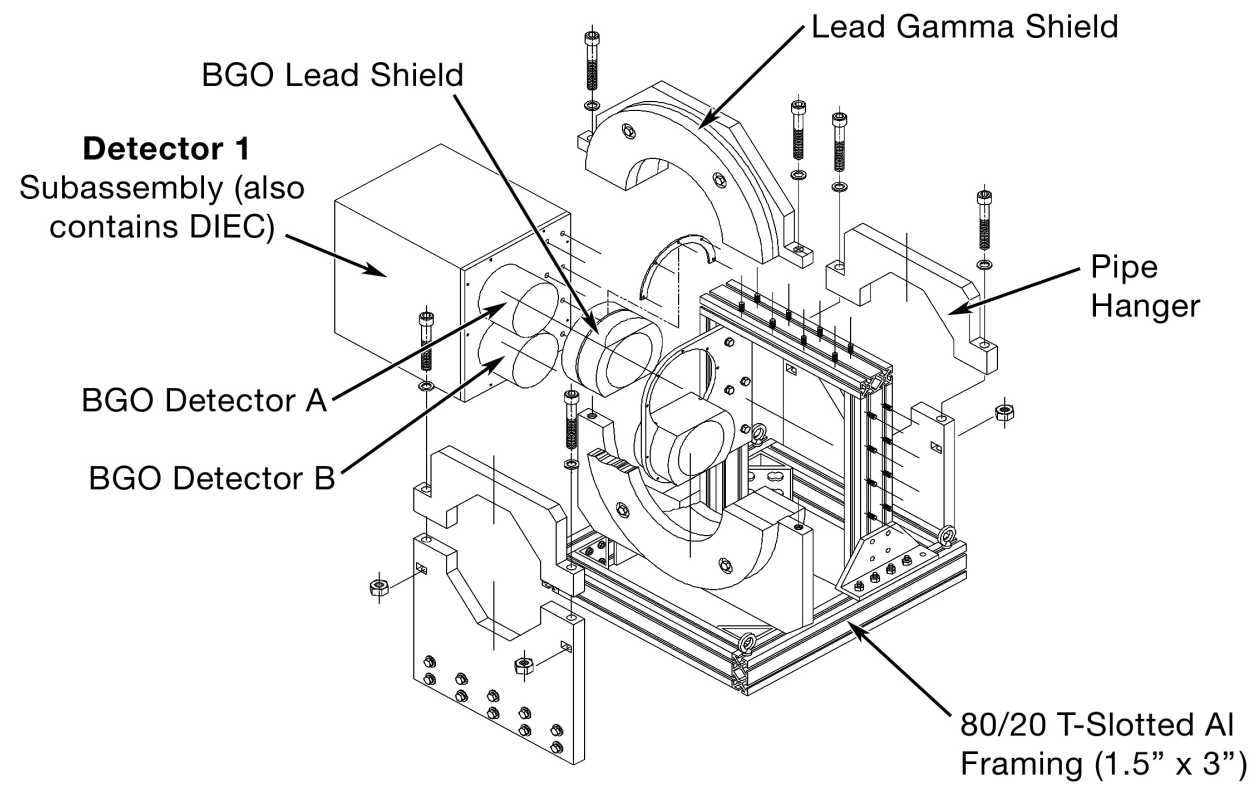

Fig. 13. FMFM detector assembly designed for 8-in.-diam UF 6 process pipes.

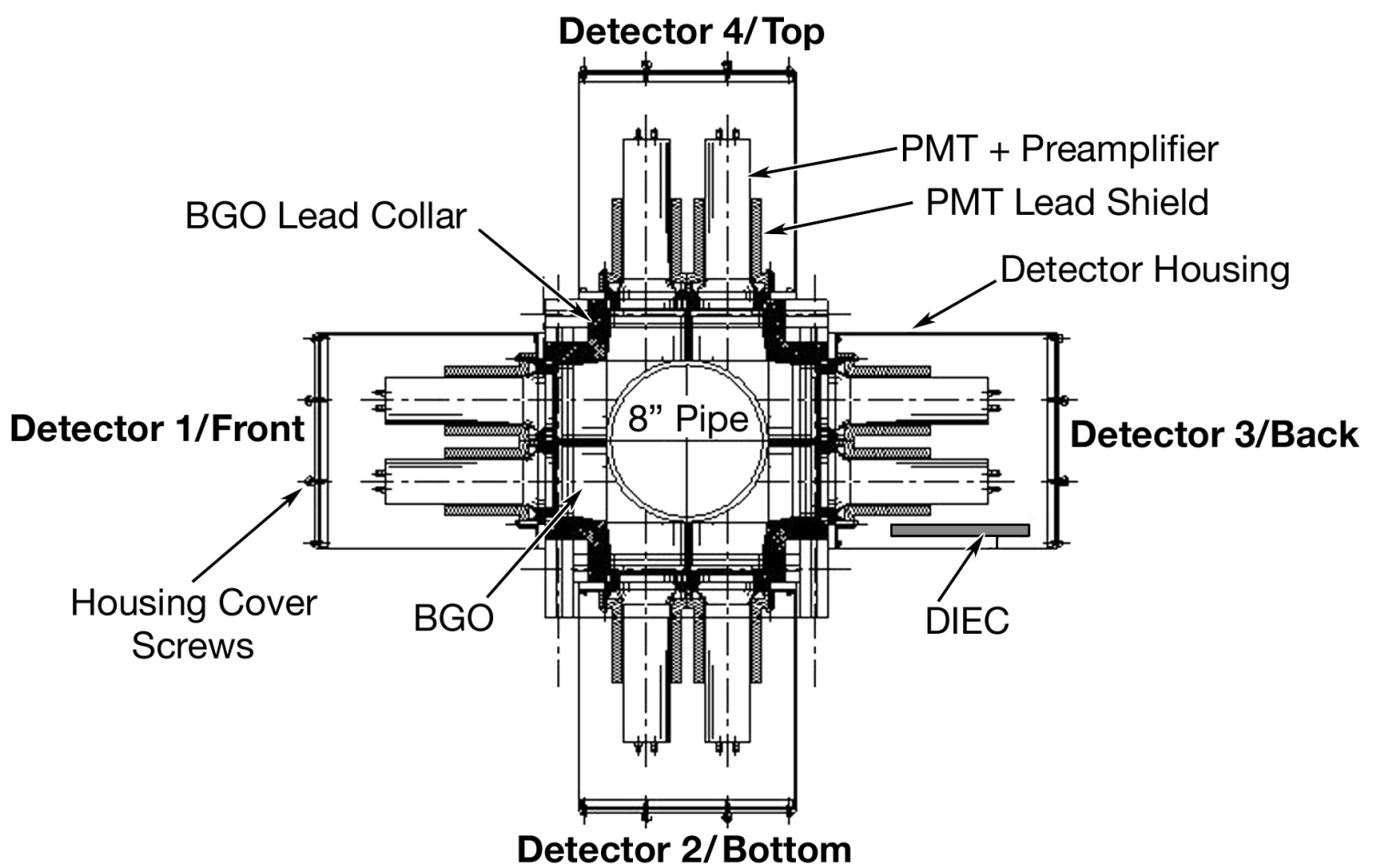

Fig. 14. Detailed engineering design drawing of the FMFM detector assembly, showing a crosssectional view around the process pipe. 


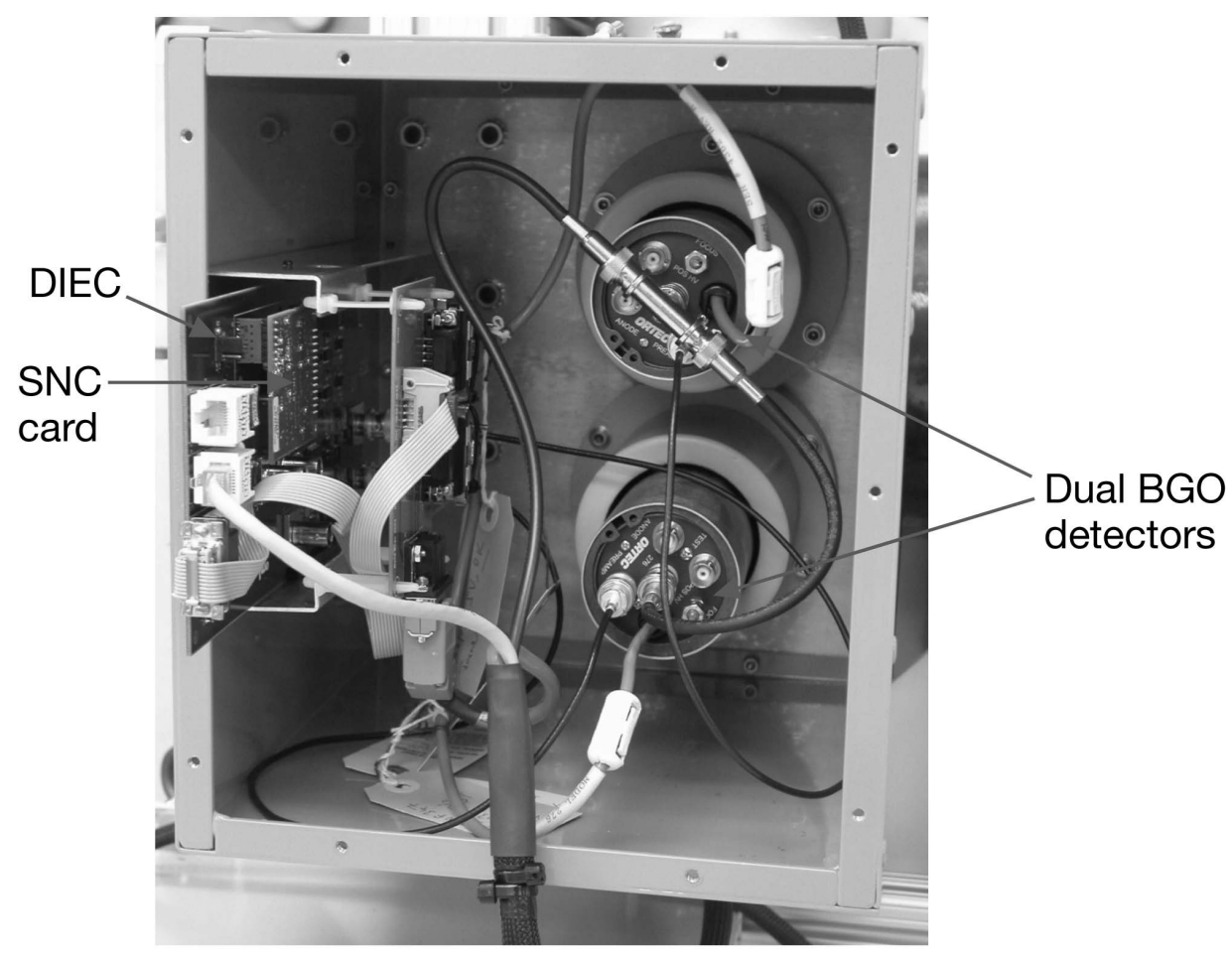

Fig. 15. Detailed view of the FMFM detector housing together with the DIEC and SNC.

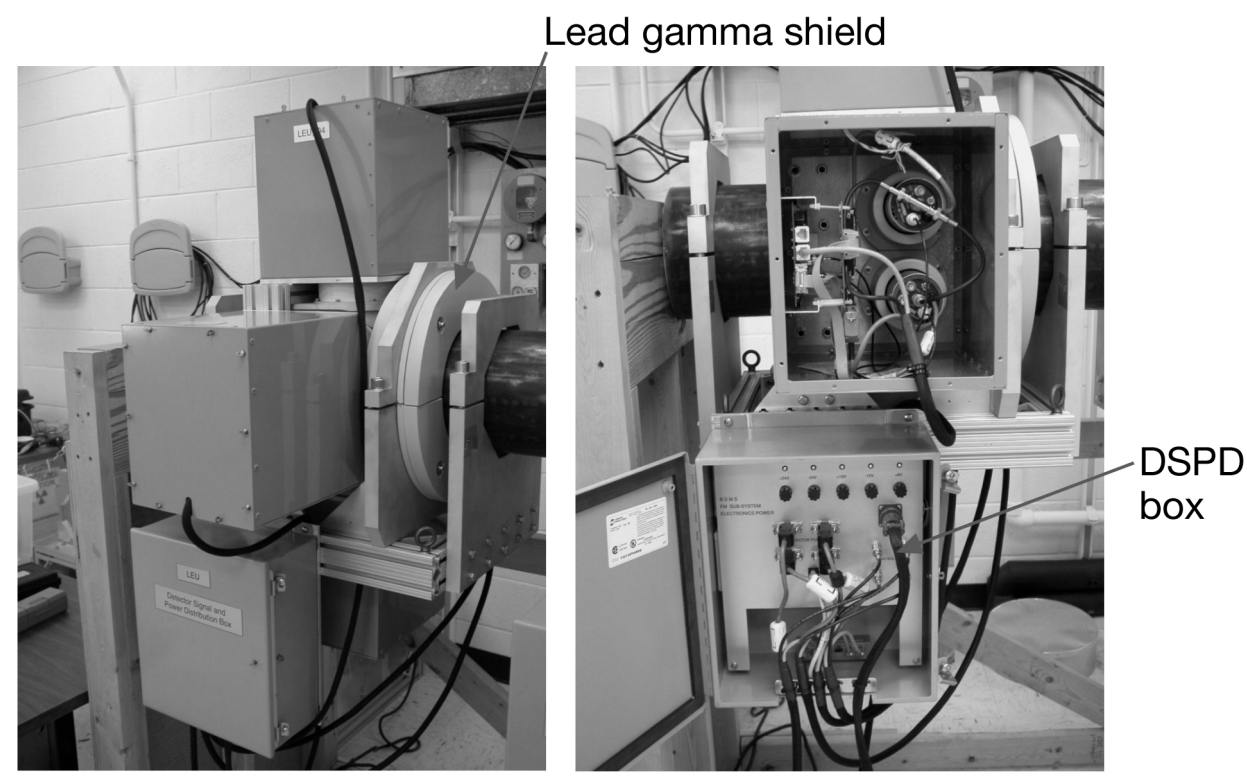

Fig. 16. Photographs of (left) the FMFM detector assembly showing the additional lead gamma shield located toward the FMFM sources to reduce the detector background signal and (right) the DSPD box. 


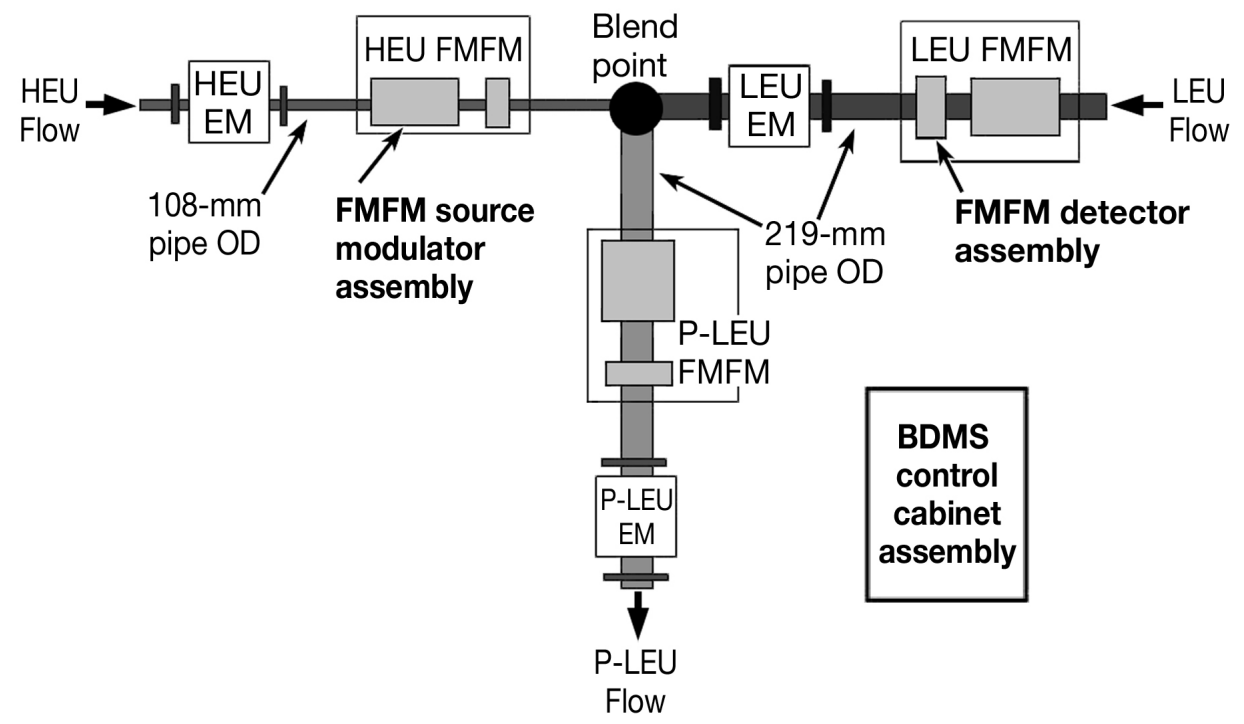

Fig. 17. Block diagram of the BDMS installation on the HEU blending system at SChE.

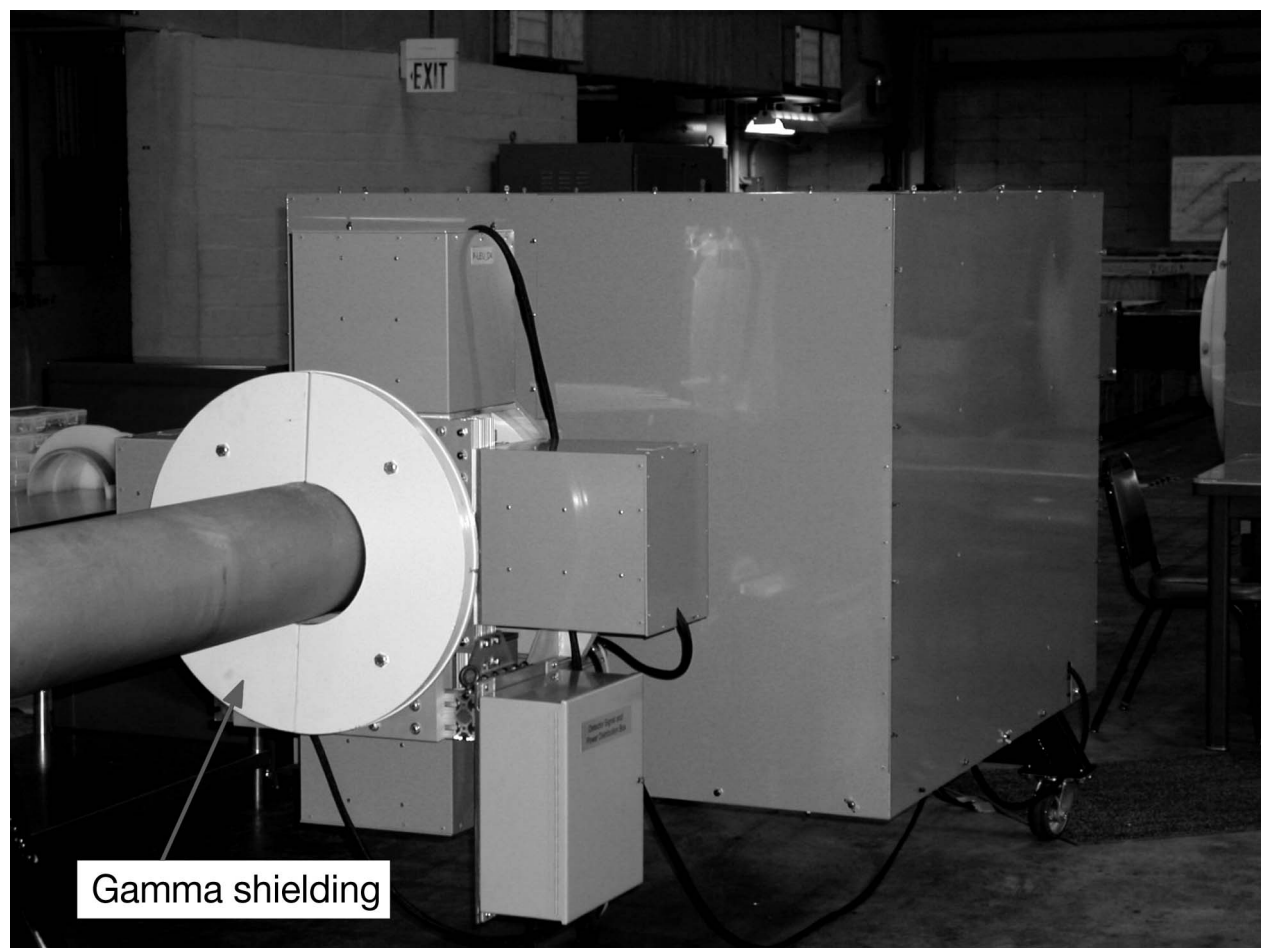

Fig. 18. Typical SChE FMFM equipment. The source modulator and detector assemblies are installed on a test stand. Additional lead gamma shielding to reduce the detector background signal is also shown. 


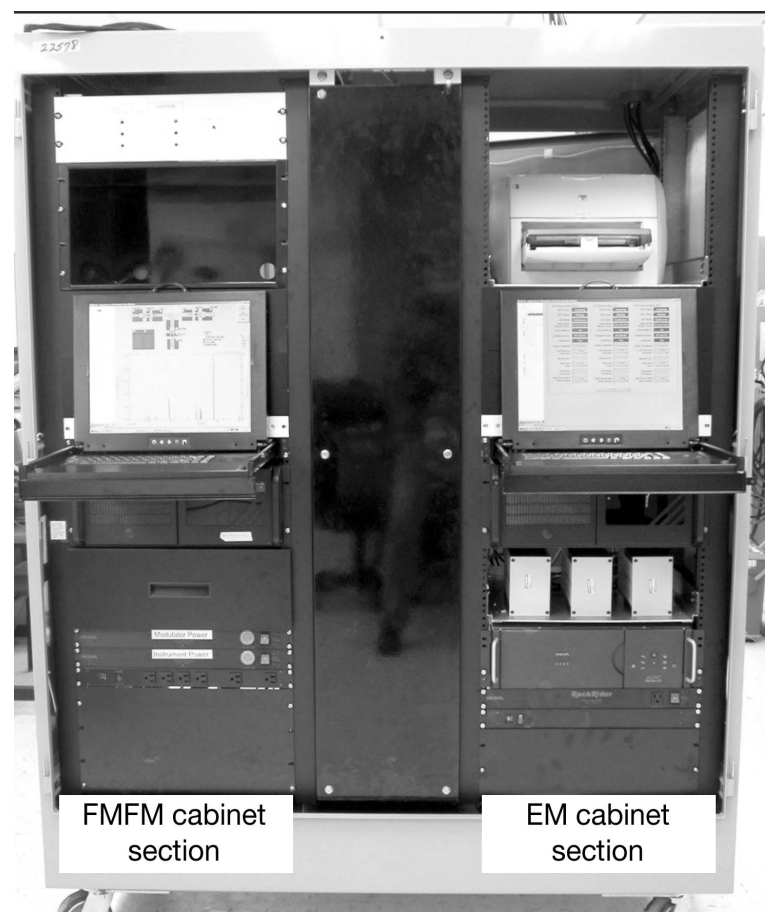

Fig. 19. BDMS main cabinet, which houses the EM and FMFM cabinet sections.

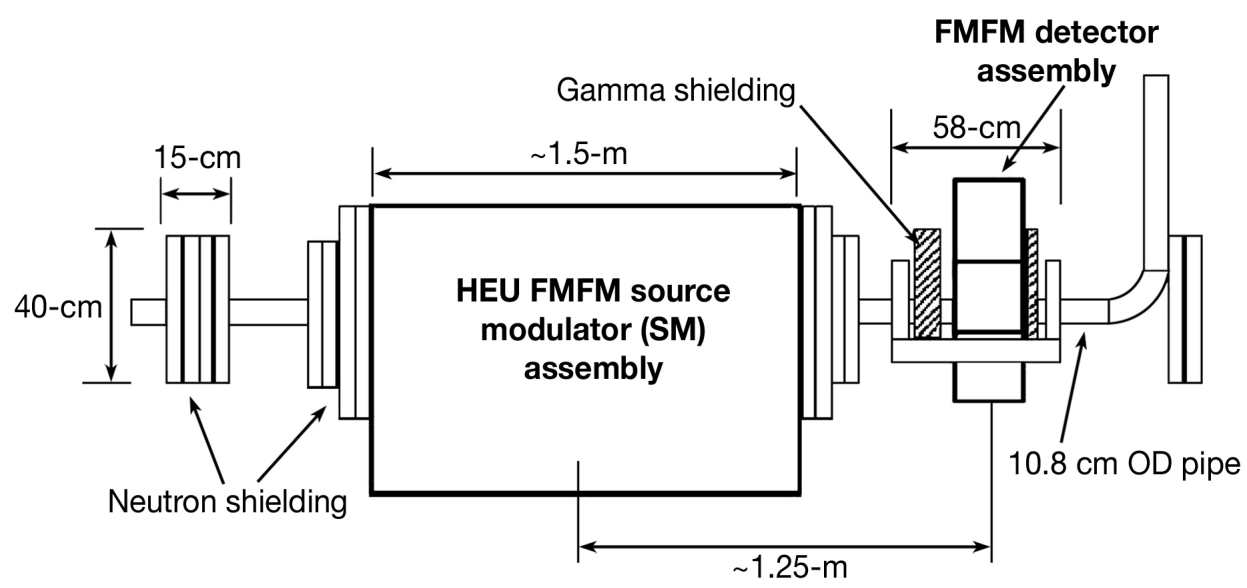

Fig. 20. Recommended FMFM installation configuration for HEU leg. 


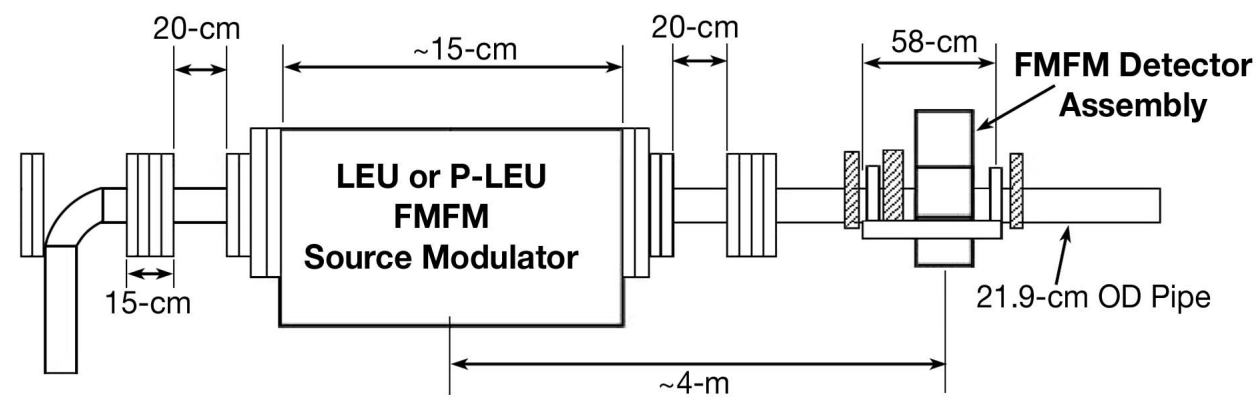

Fig. 21. Recommended FMFM installation configuration for the LEU and P-LEU legs.

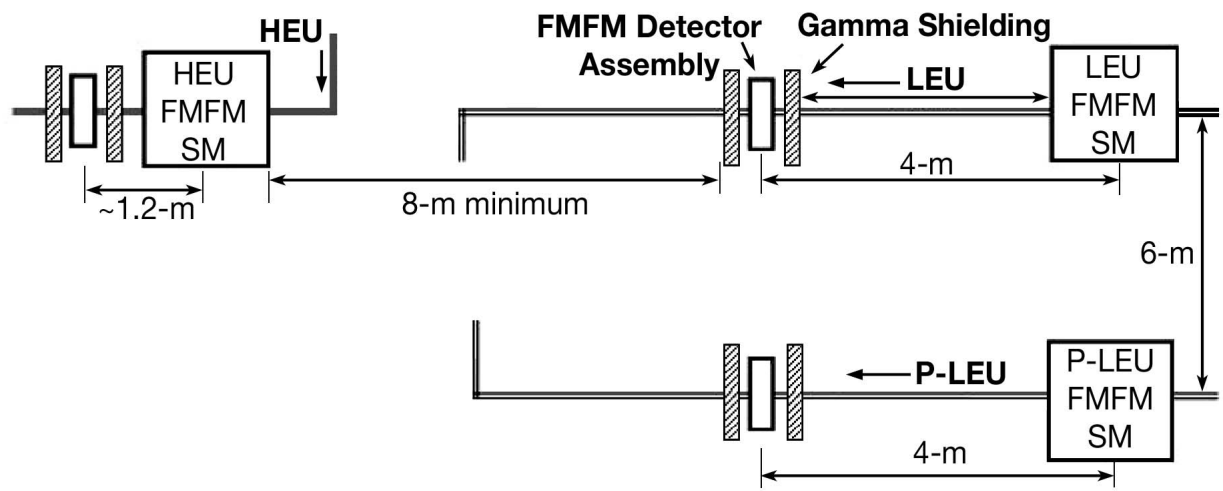

Fig. 22. Recommended FMFM installation configuration for all three legs are designed to reduce the crosstalk between the sources in the source modulators and the detectors. Pipes are about $1 \mathrm{~m}$ off the floor. 


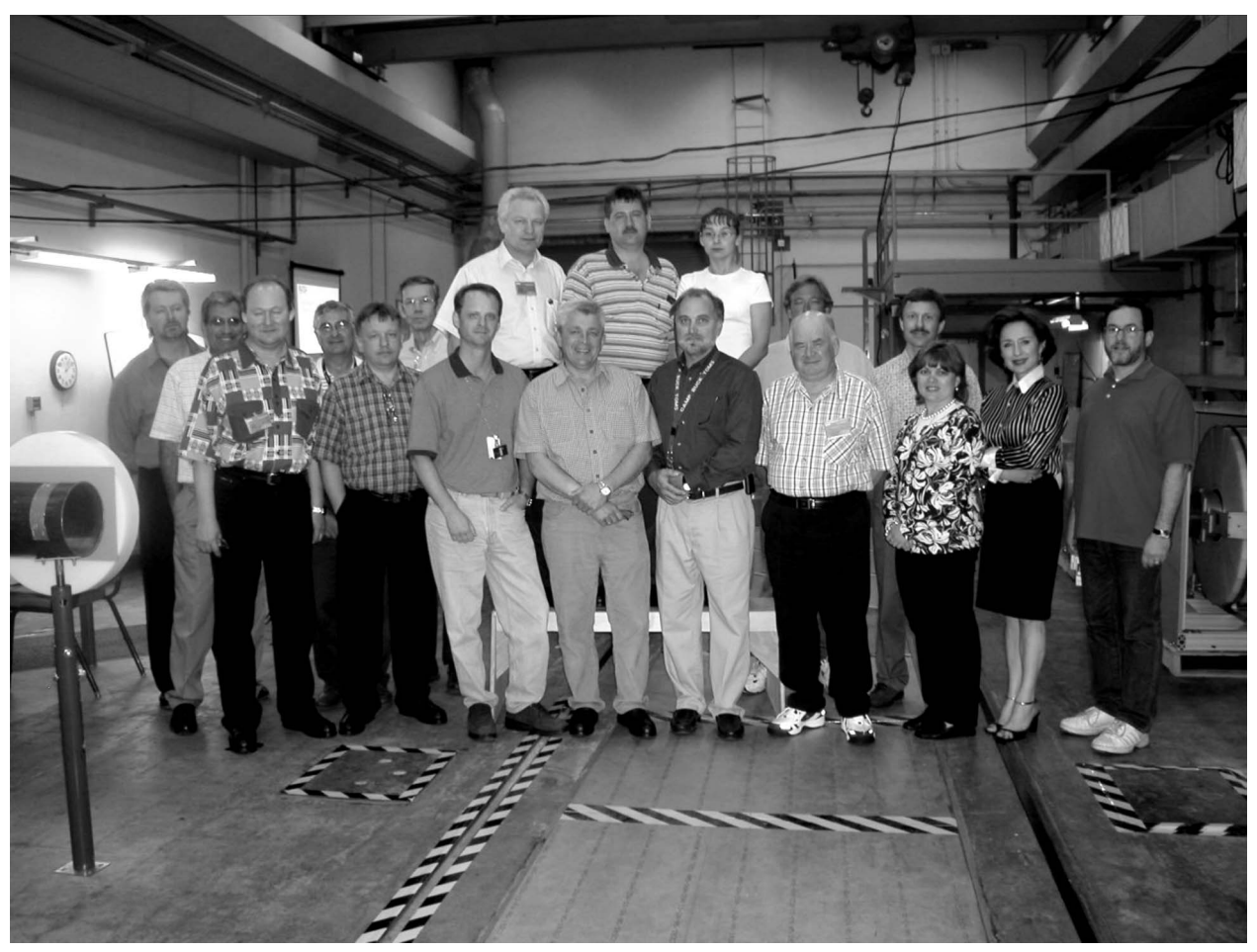

Fig. 23. SChE BDMS training for the Russian delegation at ORNL, May 17-21, 2004.

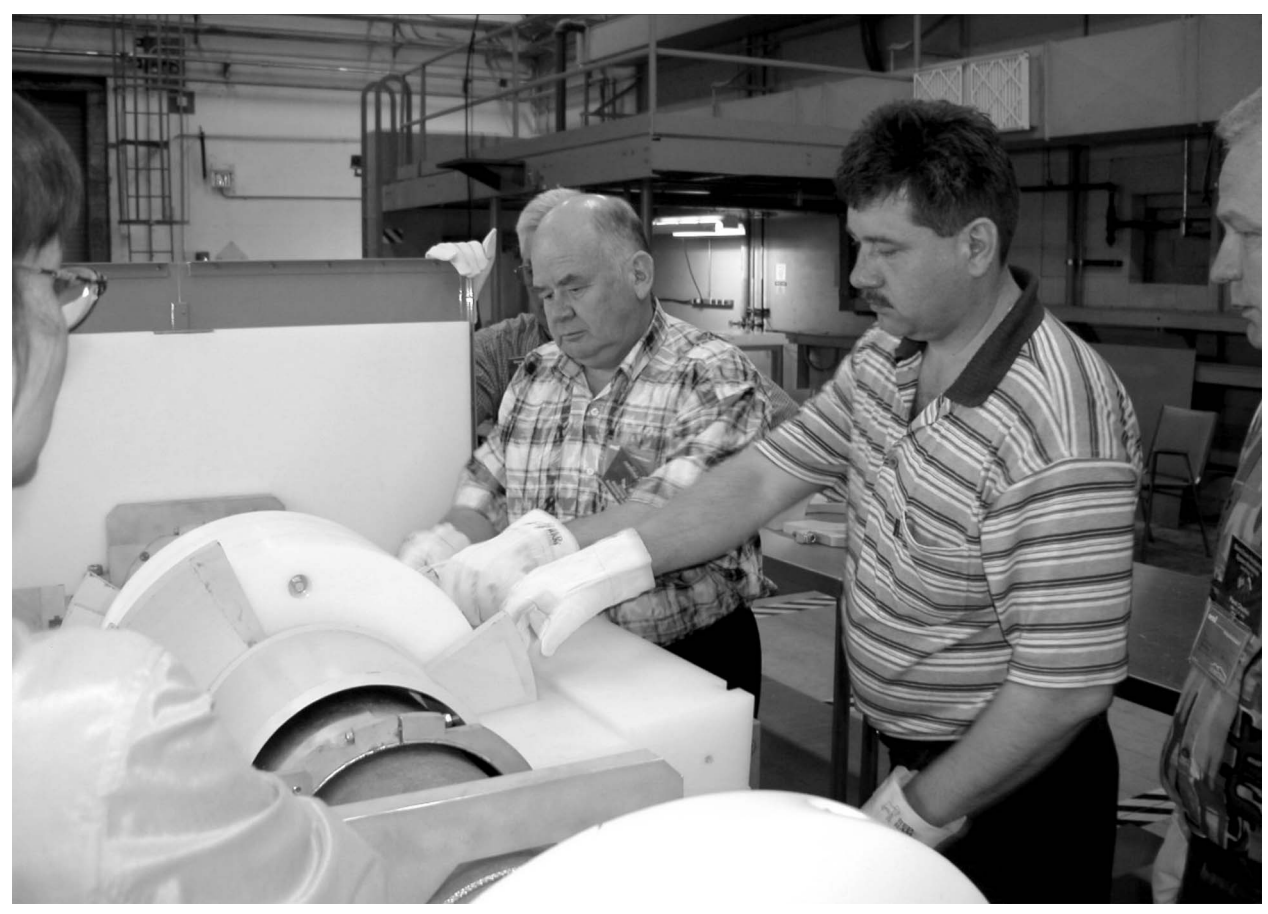

Fig. 24. The Russian delegation practicing on the source modulator installation. 


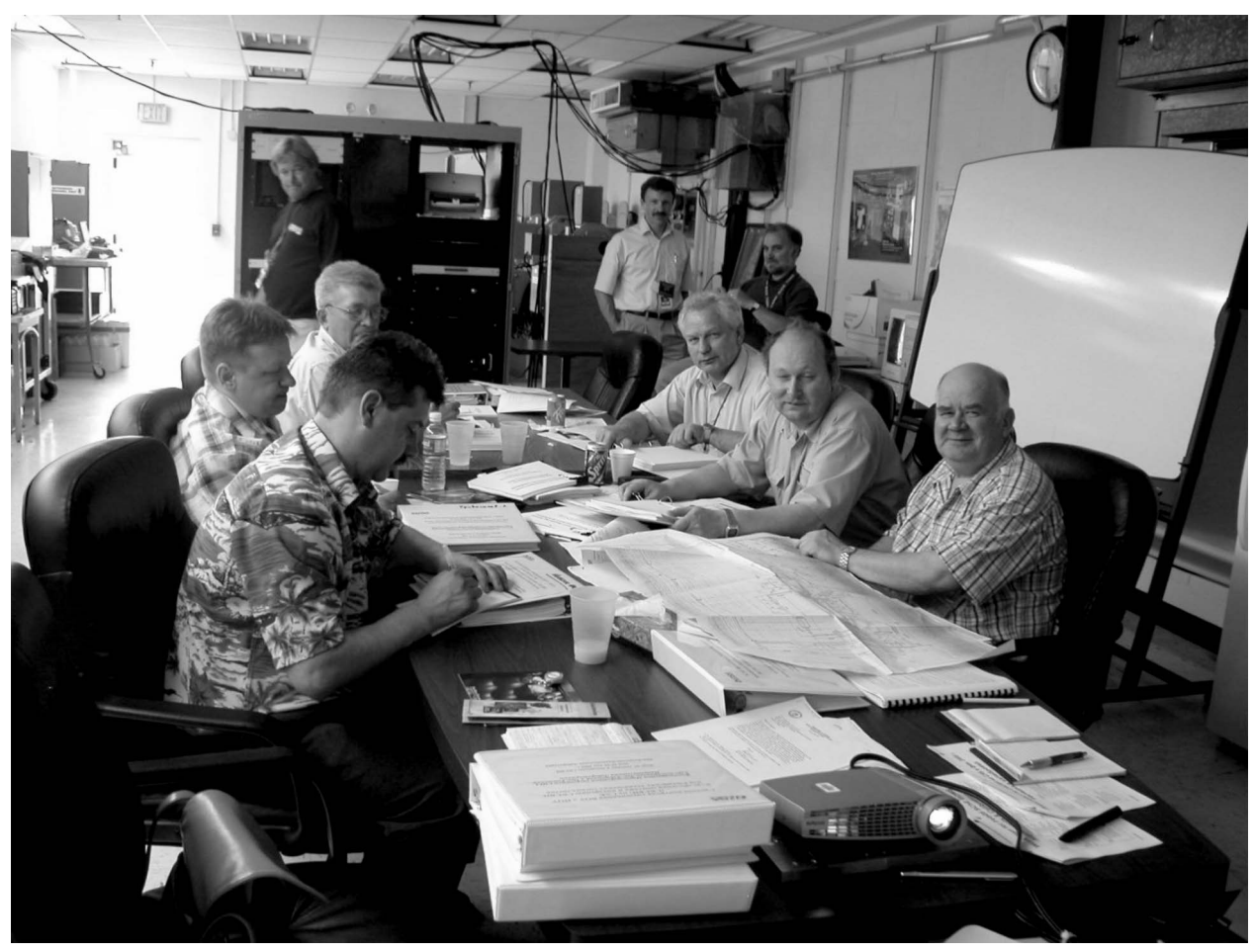

Fig. 25. The Russian delegation in a classroom discussion of the BDMS installation.

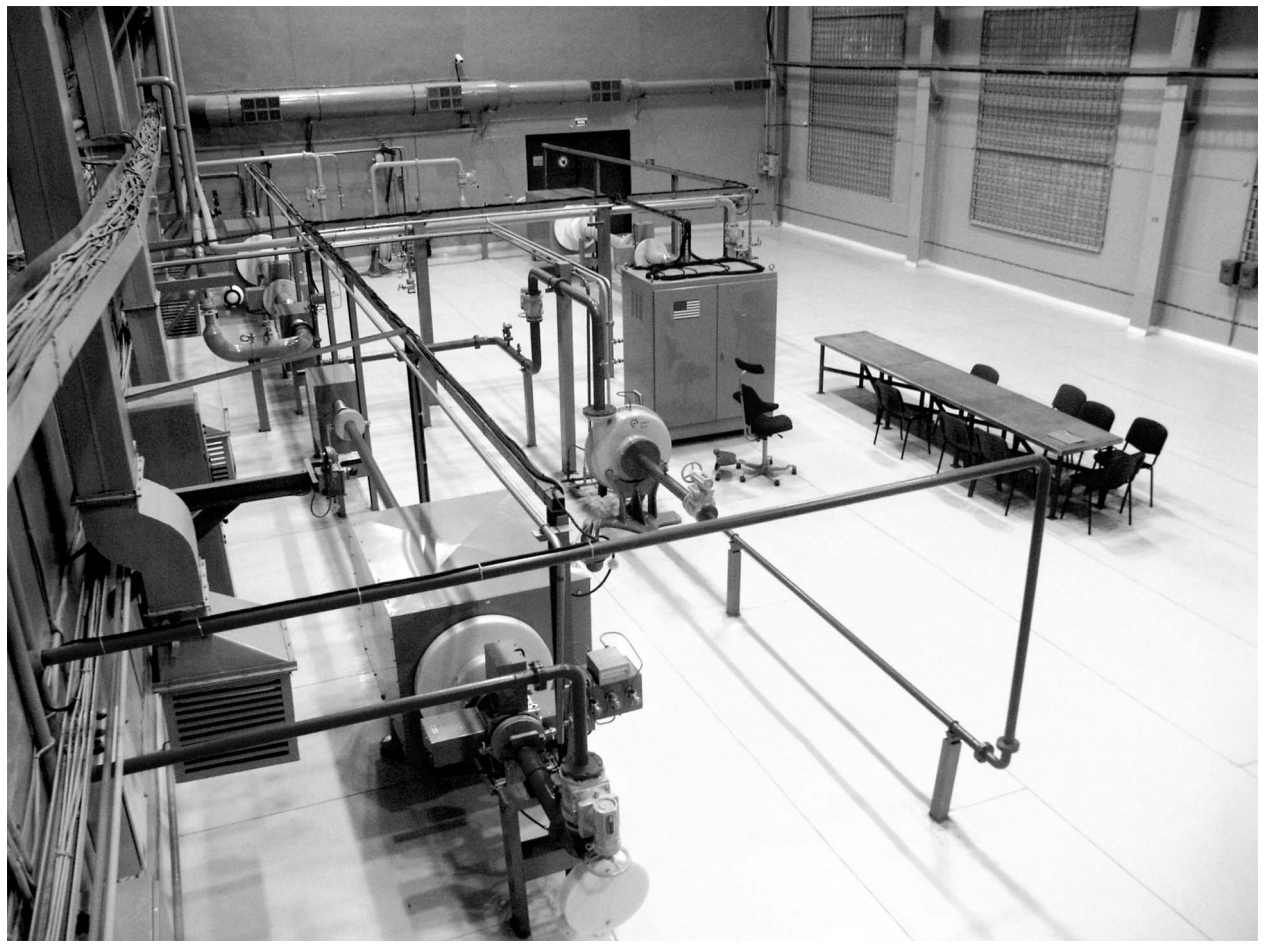

Fig. 26. BDMS equipment in the SChE Enrichment Plant BDMS room (installed in October 2004). Source: V. Afanasyev et al., "Installation of the Blend Down Monitoring System at the Siberian Group Of Chemical Enterprises, Seversk, Russia," $46^{\text {th }}$ Annual Meeting of the INMM, Phoenix, Arizona, July 20, 2005. 

6. TABLES 

Table 1. FMFM assembly dimensions and weights

\begin{tabular}{lccc}
\hline \multicolumn{1}{c}{ Major assembly } & $\begin{array}{c}\text { Number of } \\
\text { assemblies }\end{array}$ & $\begin{array}{c}\text { Dimensions, } \mathbf{L} \times \mathbf{W} \times \mathbf{H} \\
(\mathbf{c m})\end{array}$ & $\begin{array}{c}\text { Weight } \\
(\mathbf{k g})\end{array}$ \\
\hline $\begin{array}{l}\text { Control cabinet (consists of combined } \\
\text { EM and FMFM sections) }\end{array}$ & 1 & $183 \times 153 \times 92$ & 367 \\
$\begin{array}{l}\text { FMFM source and modulator assembly } \\
(10.8 \text {-cm OD Pipe) }\end{array}$ & 1 & $150 \times 100 \times 120$ & 740 \\
$\begin{array}{l}\text { FMFM source and modulator assembly } \\
(21.9-\mathrm{cm} \text { OD pipe) }\end{array}$ & 2 & $150 \times 110 \times 130$ & 950 \\
$\begin{array}{l}\text { FMFM detector and gamma-ray } \\
\text { shielding assembly (10.8-cm OD pipe) }\end{array}$ & 1 & $58 \times 91 \times 91$ & 210 \\
$\begin{array}{l}\text { FMFM detector and gamma-ray } \\
\text { shielding assembly (21.9-cm OD pipe) }\end{array}$ & 2 & $58 \times 105 \times 105$ & 420 \\
\hline
\end{tabular}

Table 2. FMFM UF 6 gas velocity ranges during operation

\begin{tabular}{lcc}
\hline \multicolumn{1}{c}{ Leg } & Flow regime & Velocity range $(\mathbf{m} / \mathbf{s})$ \\
\hline HEU & Laminar, 10.8-cm OD pipe & $0.02-0.2$ \\
LEU & Turbulent, 21.9-cm OD pipe & $0.4-1.5$ \\
P-LEU & Turbulent, , 21.9-cm OD pipe & $0.4-1.5$ \\
\hline
\end{tabular}

Table 3. FMFM flow measurement range and associated uncertainty

\begin{tabular}{lccc}
\hline \multicolumn{1}{c}{ Leg } & Flow parameter & Measurement range & Uncertainty (\%) \\
\hline HEU & Gas velocity $(\mathrm{m} / \mathrm{s})$ & $0.06-0.12$ & \pm 5 \\
LEU & Gas velocity $(\mathrm{m} / \mathrm{s})$ & $0.4-1.0$ & \pm 5 \\
P-LEU & Gas velocity $(\mathrm{m} / \mathrm{s})$ & $0.4-1.0$ & \pm 5 \\
HEU & ${ }^{235} \mathrm{U}$ fissile mass flow $(\mathrm{g} / \mathrm{s})$ & $0.27-0.54$ & \pm 25 \\
LEU & ${ }^{235} \mathrm{U}$ fissile mass flow $(\mathrm{g} / \mathrm{s})$ & $0.12-0.3$ & \pm 25 \\
P-LEU & ${ }^{235} \mathrm{U}$ fissile mass flow $(\mathrm{g} / \mathrm{s})$ & $0.4-0.9$ & \pm 25 \\
\hline
\end{tabular}

Table 4. BDMS operating pressures and the FMFM measurement results

\begin{tabular}{lcc}
\hline $\begin{array}{c}\text { Flow monitor } \\
\text { location }\end{array}$ & $\begin{array}{c}\text { Pressure at the BDMS } \\
\text { location (Torr) }\end{array}$ & $\begin{array}{c}\text { Fissile mass flow rate relative to plant } \\
\text { measurement (\%) }\end{array}$ \\
\hline HEU leg & $44 \pm 2$ & 1.5 \\
LEU leg & $55 \pm 2$ & 8.8 \\
P-LEU leg & $55 \pm 2$ & 0.2 \\
\hline
\end{tabular}





\section{REFERENCES}

1. D. Close et al., HEU Transparency Implementation, LA-UR-98-4420, September 1998.

2. J. K. Mattingly et al., "Physics Design of Fissile Mass Flow Monitoring System," $38^{\text {th }}$ Annual Meeting of the Institute of Nuclear Materials Management (INMM), Phoenix, Arizona, July 20, 1997.

3. J. March-Leuba et al., "Methodology for interpretation of Fissile Mass Flow Measurements," $38^{\text {th }}$ Annual Meeting of the INMM, Phoenix, Arizona, July 20, 1997.

4. T. Uckan et al., "Measurement Methodology of the Fissile Mass Flow Monitor for the HEU Transparency Implementation Instrumentation in Russia," $42^{\text {nd }}$ Annual Meeting of the INMM, Indian Wells, California, July 20, 2001.

5. V. Afanasyev et al., "Installation of the Blend Down Monitoring System at the Siberian Group Of Chemical Enterprises, Seversk, Russia," $46^{\text {th }}$ Annual Meeting of the INMM, Phoenix, Arizona, July 20, 2005.

6. T. Uckan et al., "Fissile Mass Flow Monitor Gamma Ray Detector System Designed for Large-Size Process Pipes," $45^{\text {th }}$ Annual Meeting of the INMM, Orlando, Florida, July 20, 2004. 



\section{INTERNAL DISTRIBUTION}

1. C. R. Brittain

2. J. A. March-Leuba

3-7. D. H. Powell

8. A. W. Riedy

9. L. J. Satkowiak

10-14. T. Uckan

15. J. D. White

16. Central Research Library

17. ORNL Laboratory Records - RC

18. ORNL Laboratory Records - OSTI

\section{EXTERNAL DISTRIBUTION}

19. Janie Benton, U. S. Department of Energy, NA-23/Germantown Building, 1000 Independence Avenue, S.W., Washington, DC 20585-1290

20. Dianna Blair, Sandia National Laboratory, International Programs, 10600 Research Road, Albuquerque, NM 87123

21. Cynthia Boggs, Argonne National Laboratory, 270 Corporate Square Bldg., 1000 Independence Ave., SW, Washington, DC 20585-0270

22. David Dougherty, U. S. Department of Energy, NA-241, 1000 Independence Avenue, S.W., Washington, DC 20585

23. Melvin Feather, II, SAIC, 20201 Century Blvd., Suite 300, Germantown, MD 20874

24-28. Joseph Glaser, U. S. Department of Energy, NA-23, 1000 Independence Avenue, S.W., Washington, DC 20585-1290

29. Tom Hill, Los Alamos National Laboratory, P.O. Box 1663, MS B228, Los Alamos, New Mexico, 87545

30. Dennis Meyers, U.SS. Department of Energy, NA-23/Germantown Building, 1000 Independence Avenue, S.W., Washington, DC 20585-1290

31. Calvin Moss, Los Alamos National Laboratory, P.O. Box 1663, MS B228, Los Alamos, New Mexico 87545

32. Radoslav Radev, Lawrence Livermore National Laboratory, P. O. Box 808, Livermore, CA 94551

33. Robert Richmond, Bechtel Nevada, P. O. Box 380, Suitland, MD 20752

34. Kurt Siemon, Jr., U. S. Department of Energy, NA-241, 1000 Independence Ave., S.W., Washington, DC 20585

35. David Wall, U. S. Department of Energy, NNSA, Y-12 Site Office, MS 8009, 200 Administration Road, Oak Ridge, TN 37831 


\section{DRAWING NUMBERS}

\begin{tabular}{|c|c|}
\hline Figure & Asset number \\
\hline 1 & $2005-02493$ \\
\hline 2 & 2005-02494 \\
\hline 3 & 2005-02495 \\
\hline 4 & $2005-02496$ \\
\hline 5 & 2005-02497 \\
\hline 6 & $2005-02498$ \\
\hline 7 & 2005-02499 \\
\hline 8 & $2005-02500$ \\
\hline 9 & $2005-02501$ \\
\hline 10 & 2005-02502 \\
\hline 11 & $2005-02503$ \\
\hline 12 & $2005-02504$ \\
\hline 13 & 2005-02505 \\
\hline 14 & 2005-02506 \\
\hline 15 & $2005-02507$ \\
\hline 16 & $2005-02508$ \\
\hline 17 & $2005-02509$ \\
\hline 18 & $2005-02510$ \\
\hline 19 & $2005-02511$ \\
\hline 20 & $2005-02512$ \\
\hline 21 & $2005-02513$ \\
\hline 22 & $2005-02514$ \\
\hline 23 & $2005-02515$ \\
\hline 24 & $2005-02516$ \\
\hline 25 & $2005-02517$ \\
\hline 26 & $2005-02518$ \\
\hline
\end{tabular}

